\title{
Magnitude and Frequency of Floods in Western Oregon
}

By D. D. Harris, Larry L. Hubbard, and Lawrence E. Hubbard

U.S. GEOLOGICAL SURVEY

Open-File Report 79-553

Prepared in cooperation with the

OREGON DEPARTMENT OF TRANSPORTATION,

HIGHWAY DIVISION

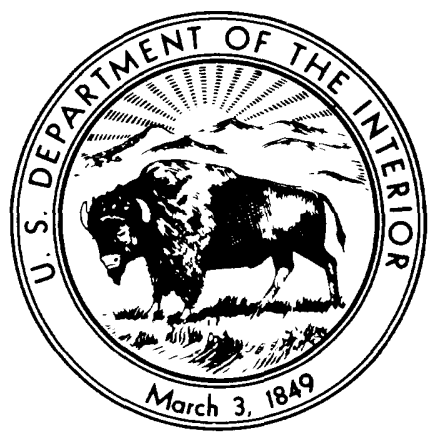


UNITED STATES DEPARTMENT OF THE INTERIOR

CECIL D. ANDRUS, Secretary

GEOLOGICAL SURVEY

H. William Menard, Director

For additional information write to:

U.S. GEOLOGICAL SURVEY

P.O. Box 3202

Portland, Oregon 97208 


\section{Contents}

Page

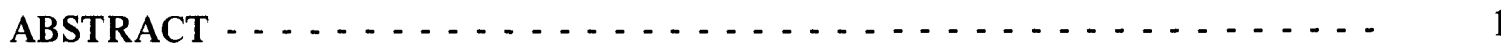

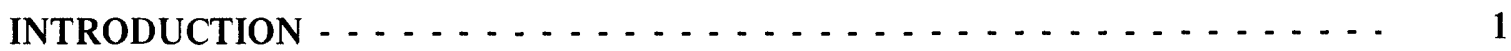

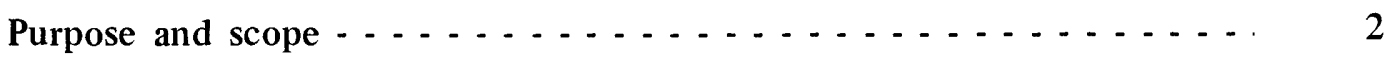

Previous studies ............................... 2

GENERAL DESCRIPTION OF THE AREA ................. 2

ANALYTICAL TECHNIQUE $\ldots \ldots \ldots \ldots \ldots \ldots$

Drainage-basin characteristics . . . . . . . . . . . . . . . 4

Magnitude and frequency of floods at gaged sites ............ 5

Regression analysis ........................ . . . 5

APPLICATION OF RESULTS $\ldots \ldots \ldots \ldots \ldots$

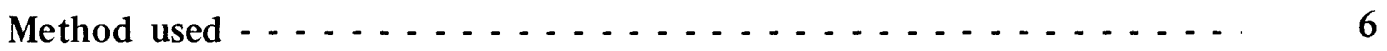

Evaluation of estimates $\ldots \ldots \ldots \ldots \ldots$

Illustrative problems ... . . . . . . . . . . . . . . 10

Limitations . . . . . . . . . . . . . . . . . . . . . . 13

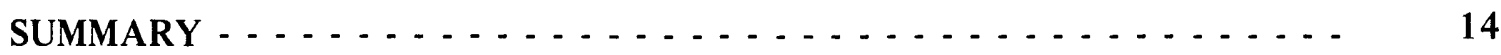

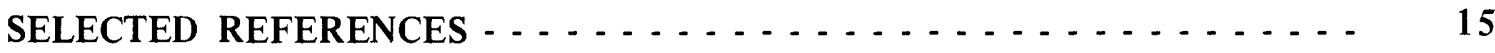




\section{Illustrations}

Page

Plate 1. Map showing locations of gaging stations in western Oregon - - - In pocket

2. Map showing isopluvial of 2-year, 24-hour precipitation in tenths

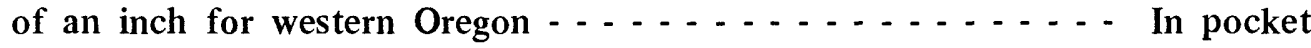

Figure 1. Index map showing flood-frequency regions of western Oregon - - 3

2. Graph showing maximum observed peak discharges in relation

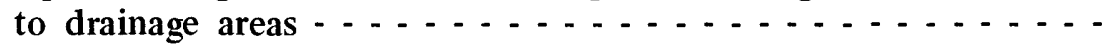

3. Graph showing flood-frequency curve developed by regional

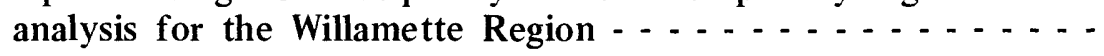

\section{Tables}

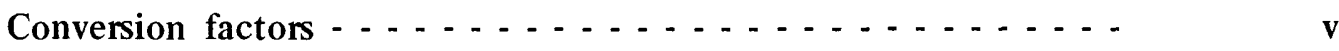

Table 1. Regional flood-frequency equations . . . . . . . . . . . 7

2. Basin characteristics used in multiple regression .......... 16

3. Maximum discharges at gaging stations used in western Oregon

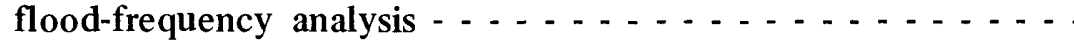

4. Discharges for selected flood frequencies at gaging stations - . - - 
Conversion factors for inch-pound system and International System Units (SI) [For use of those readers who may prefer to use metric units rather than inch-pound units, the conversion factors for the terms used in this report are listed below:]

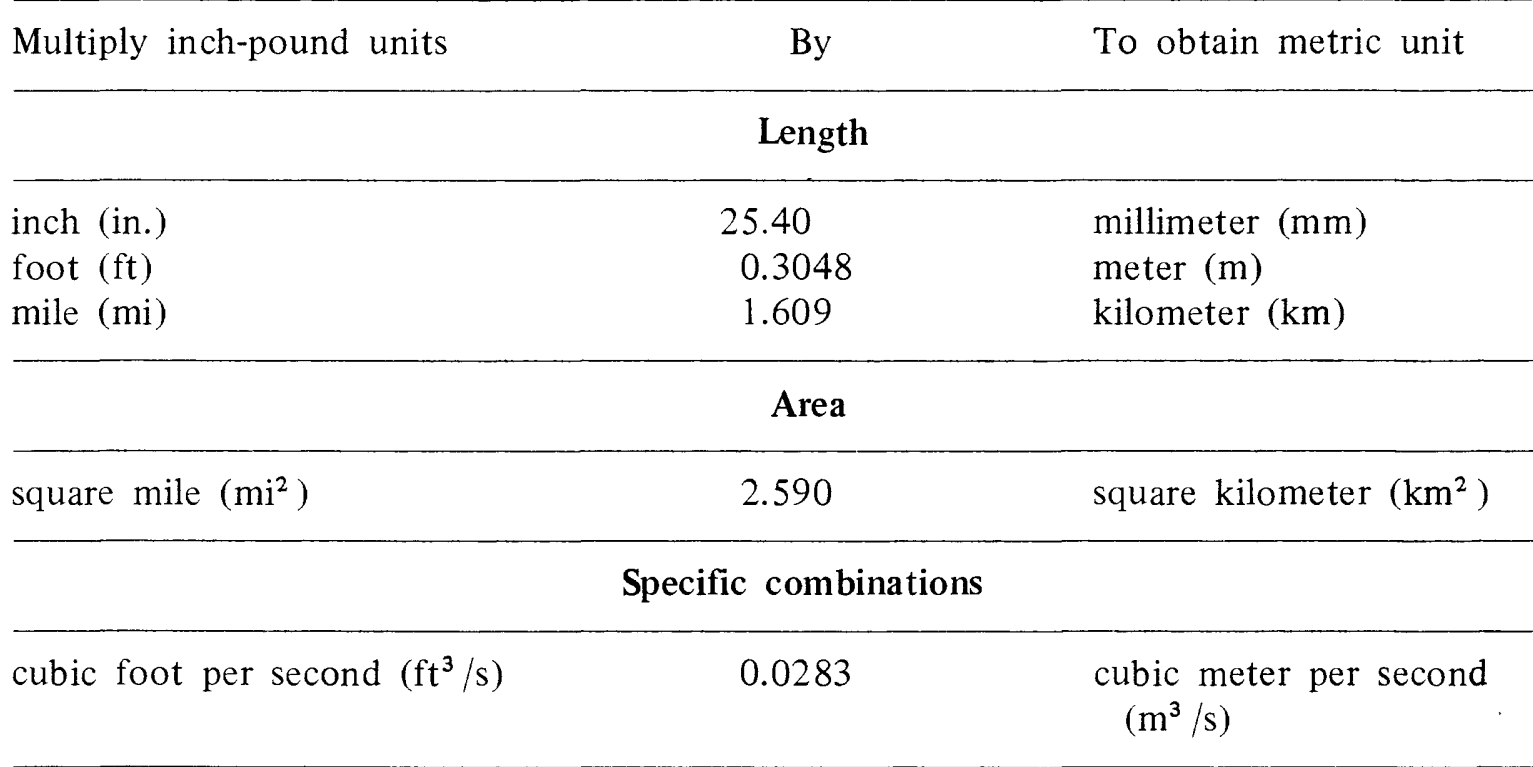




\title{
Magnitude and Frequency of Floods in Western Oregon
}

\author{
By D. D. Harris, Larry L. Hubbard, and Lawrence E. Hubbard
}

\begin{abstract}
A method for estimating the magnitude and frequency of floods is presented for unregulated streams in western Oregon. Equations relating flood magnitude to basin characteristics were developed for exceedance probabilities of 0.5 to 0.01 (2- to 100-year recurrence intervals). Separate equations are presented for four regions: Coast, Willamette, Rogue-Umpqua, and High Cascades.

Also presented are values of flood discharges for selected exceedance probabilities and of basin characteristics for all gaging stations used in the analysis. Included are data for 230 stations in Oregon, 6 stations in southwestern Washington, and 3 stations in northwestern California. Drainage areas used in the analysis range from 0.21 to 7,280 square miles. Also included are maximum discharges for all western Oregon stations used in the analysis.
\end{abstract}

\section{INTRODUCTION}

A special need for updated flood-frequency information for Oregon results from recent emphasis on flood-plain zoning, flood insurance, and design adequacy of hydraulic structures. Studies of flood magnitude and frequency are based on analyses of available streamflow records. Very few long-term records for streams with less than $10 \mathrm{mi}^{2}$ of drainage area were available when the last flood-frequency reports were prepared for Oregon by the U.S. Geological Survey. Many data have been collected since a small-stream flood-data program was started in 1952 in cooperation with the Oregon State Highway Commission (now Oregon Department of Transportation, Highway Division). This program was expanded in 1965, through funds provided by the U.S. Forest Service, to include many previously unsampled areas in national forests. Inclusion of these data has enlarged the flooddata base, both areally and in range of basin size.

This analysis was limited to western Oregon, because of the large number of gagingstation records available for the western part of the State and the deficiency of peak-flow information for many areas of the eastern part. Limiting the analysis to western Oregon allows timely use of urgently needed flood information in a rapidly developing area. An eastern Oregon flood-frequency analysis will be presented in a later report.

In describing flood frequency in this report, the term "exceedance probability" is used in preference to the term "recurrence interval." However, both terms are used in most of the tables, graphs, and illustrative problems. For example, a flood with a 0.01 exceedance probability is a flood that has one chance in a hundred of being exceeded in any one year. This is a 100-year flood under the "recurrence interval" terminology. 


\section{Purpose and Scope}

This report describes methods for evaluating the magnitude and frequency of floods at sites on streams with natural flow. The purpose is to provide a method to estimate flood magnitude and frequency at ungaged sites in western Oregon. The report is based on data from all unregulated streams (or data from regulated streams prior to their regulation) where gaging stations have been operated for at least 10 years.

Records at the gaging stations provided the basis for estimating flood-peak discharges and frequency of occurrence at ungaged sites. Stations used in this analysis have records ranging from 10 to 70 years. Peak-flow records of 230 gaging stations are available for western Oregon, 73 of which are crest-stage gaging stations that have drainage areas as small as 0.21 $\mathrm{mi}^{2}$. Locations of the gaging stations are shown on plate 1.

The magnitude of a flood is influenced by physiographic characteristics of the drainage basin. These characteristics, which include climate, topography, geography, soils, and vegetation, are referred to as basin characteristics throughout this report.

Multiple-regression analysis was used to correlate flood discharges with selected basin characteristics and to develop appropriate regional relation equations. Although many basin characteristics were determined and investigated, the number retained in the equations was reduced for simplicity and practicality, without undue sacrifice of the accuracy of the flow estimate. The characteristics used were selected on the basis of the results of prior investigations, ease of determination, and the results of the regression analysis.

\section{Previous Studies}

A previous flood-frequency report by Hulsing and Kallio (1964), covering the Pacific slope basins in Oregon and lower Columbia River basin, contains peak-flow records for 173 gaging stations in western Oregon. Of these, 22 are for crest-stage gaging stations on small streams.

Regression equations for flood-peak discharge are presented in a report, "Evaluation of the streamflow data program in Oregon" (Lystrom, 1970), that is based on data from all stations with 10 or more years of record of unregulated flow through the 1967 water year (October 1966 through 1967).

\section{GENERAL DESCRIPTION OF THE AREA}

The area studied includes all that part of Oregon west of the crest of the Cascade Range. The principal physiographic areas in western Oregon include the Coast and Cascade Ranges and the Willamette, Rogue, and Umpqua River valleys, as shown in figure 1.

The western slope of the Coast Range is influenced directly by ocean-spawned storms and weather. Annual precipitation is commonly 60 to 80 in. in the area; some coastal mountains receive as much as 200 in. (U.S. Weather Bureau, 1964). Snowmelt is not normally a major factor in flooding.

In the Willamette, Rogue, and Umpqua River valleys, high streamflows are created by storms from the Pacific Ocean. High flows in some streams draining from the Cascade Range frequently are caused by runoff from snowmelt in combination with direct rainfall runoff. The proportional contributions from each source are difficult, if not impossible, to identify. Annual precipitation amounts range from lows of less than $20 \mathrm{in}$. in the Rogue River basin to more than 100 in. in the lower elevations of the Cascade Range.

In the higher elevations of the Cascade Range, flood peaks are predominantly from snowmelt runoff combined with heavy rainfall runoff. Much of the precipitation in this area falls as snow in late fall, winter, and early spring. Annual precipitation ranges from less than 20 in. in the south to more than 100 in. in the north. 


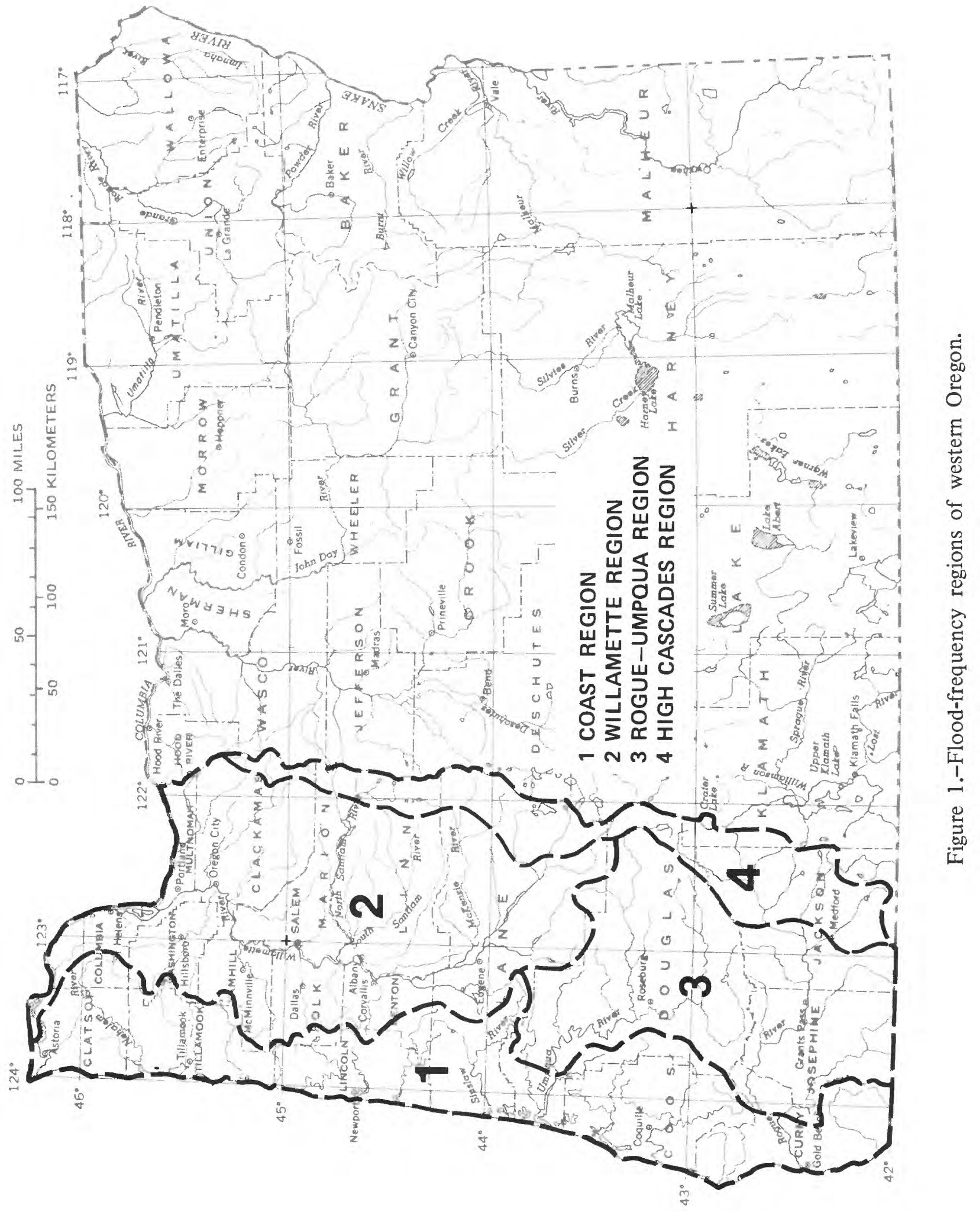




\section{ANALYTICAL TECHNIQUE}

Flood-frequency characteristics for gaged sites were related to drainage-basin characteristics by the multiple-regression technique to define regional flood magnitudefrequency relations.

\section{Drainage-Basin Characteristics}

The drainage-basin characteristics computed for each gaging station and used as an independent variable in the multiple-regression study are listed in table 2 at the back of the report and are defined as follows:

1. Drainage area (A), in square miles, the total contributing area upstream from the gaging-station site, as shown in the latest Geological Survey water-resources data reports.

2. Main-channel slope (S), in feet per mile, determined from elevations at points 10 and 85 percent of the distance along the channel from the gaging station to the divide. This index was described and used by Benson (1962b, 1964).

3. Main-channel length (L), in miles, from the gaging station to the basin divide, measured in accordance with guidelines given by the U.S. Water Resources Council (1968) or taken in part from the various River Mile Index publications prepared by the Hydrology and Hydraulics Committee of the Pacific Northwest River Basins Commission (1963-68).

4. Mean basin elevation (E), in feet above mean sea level, determined by the grid method from quadrangle map of a practical scale by laying a grid over the map, recording the elevation at each grid intersection, and averaging those elevations. The grid spacing was selected to give at least 25 intersections within the basin boundary.

5. Area of lakes and ponds (ST), expressed as a percentage of the drainage area, determined from the most recent quadrangle maps available.

6. Forest cover $(\mathrm{F})$, expressed as the percentage of the drainage area covered by forests, as shown on the most recent quadrangle maps available.

7. The values of soils index (SI), determined from a map compiled from computed values of soils indexes according to procedures described by the Soil Conservation Service $(1959,1964)$. Data for these computations were derived from soilsassociation and land-use maps included in the Columbia North-Pacific Framework Study (unpub. manuscript). Data were also furnished by the Soil Conservation Service staff, State office, Portland, Oreg.

8. Azimuth (AZ), in degrees from north, of a straight line connecting points 85 and 10 percent of distance from gage to divide.

9. Latitude at gage (LAT). Latitude of stream-gaging station in decimal degrees.

10. Longitude of gage (LONG). Longitude of stream-gaging station in decimal degrees.

11. Mean annual precipitation (P), in inches, determined from an isohyetal map prepared by the National Weather Service River Forecast Center, Portland, Oreg., (U.S. Weather Bureau, 1964), using adjusted climatological data (1930-57) and values derived by correlation with other physiographic factors.

12. Precipitation intensity (I), defined as the maximum 24-hour rainfall having a recurrence interval of 2 years (2-year, 24-hour rainfall), expressed in inches. These values were determined by the grid method, using plate 2 which was prepared by U.S. National Oceanic and Atmospheric Administration (NOAA) (1973).

13. Temperature index (TI), the mean minimum January temperature, in degrees Fahrenheit, in the basin. This value was determined from a U.S. Weather Bureau publication (Sternes, 1960). 


\section{Magnitude and Frequency of Floods at Gaged Sites}

Methods for estimating flow frequencies at gaged sites, presented in "Guidelines for Determining Flood Flow Frequency," published by the U.S. Water Resources Council (1977) were used in this study. Data from 230 gaging stations in Oregon, 6 in southwestern Washington, and 3 in northern California, representing basins that have virtually natural flow conditions and 10 years or more of record, provided the basic dependent variables (annual peak discharge). Historic flood information was used, when available, to supplement the systematic gaging-station record. For each station, the logarithms of the annual peaks were used to compute the mean, standard deviation, and skew coefficient that describe a log-Pearson Type-III distribution.

Frequency data from the log-Pearson Type-III frequency curve for each station are presented in table 4 at the back of the report. It lists flows for exceedance probabilities of $\mathrm{Q}_{0.5}(2 \mathrm{yr}), \mathrm{Q}_{0.2}(5 \mathrm{yr}), \mathrm{Q}_{0.10}(10 \mathrm{yr}), \mathrm{Q}_{0.04}(25 \mathrm{yr}), \mathrm{Q}_{0.02}(50 \mathrm{yr})$, and $\mathrm{Q}_{0.01}$ (100 yr). The figures in parentheses are the corresponding recurrence intervals. As an example, if a flow of $900 \mathrm{ft}^{3} / \mathrm{s}$ is shown under an exceedance probability of 0.5 in the table, it means that there is a 50 percent chance that the flow at the gaging station will exceed $900 \mathrm{ft}^{3} / \mathrm{s}$ in any one year. Another way of describing the same peobability is that a $900-\mathrm{ft}^{3} / \mathrm{s}$ flow has a 2 -year recurrence interval. A flow shown under an exceedance probability of 0.01 has a 1 percent chance of being exceeded in any one year. (It could be described as having a 100-year recurrence interval.)

\section{Regression Analysis}

Multiple-regression analyses were used to define equations expressing flood discharges of selected exceedance probabilities as a function of the basin characteristics. This relation may be expressed by the mathematical model

$$
\mathrm{QT}_{\mathrm{T}}=\mathrm{K} \mathrm{\textrm {C } _ { 1 }}{ }^{\mathrm{a}} \mathrm{C}_{2} \mathrm{~b}_{\mathrm{C}_{3}}{ }^{\mathrm{c}} \ldots \mathrm{C}_{\mathrm{n}}{ }^{\mathrm{n}}
$$

in which $\mathrm{Q}_{\mathrm{T}}$ is the discharge for a selected exceedance probability, $\mathrm{T} ; \mathrm{K}$ is a regression constant; $\mathrm{C}_{1}, \mathrm{C}_{2}, \mathrm{C}_{3}$, and $\mathrm{C}_{\mathrm{n}}$ are basin characteristics; and $\mathrm{a}, \mathrm{b}, \mathrm{c}$, and $\mathrm{n}$ are regression coefficients. A step-backward regression analysis of the variables was made using a STATPAC data matrix. The least significant independent variable (basin characteristic) was deleted at each step. An evaluation of the standard errors for the various steps of the multiple regression was made to determine the most suitable regional equation.

The program computes the logarithms of the regression constant, the exponents of the independent variables, and the logarithm of the standard error of estimate.

Data for the 230 gaging stations in western Oregon were used for the "first try" of regression equations. The residuals (the difference between the logarithms of the flood discharges estimated from the gaging-station record and the logarithms of the flood discharges estimated from the regression equations) were plotted on a map of western Oregon. This plot and topographic maps were evaluated to delineate the boundaries of the four flood-frequency regions selected for use in the regression analysis. These four regions (Coast, Willamette, Rogue-Umpqua, and High Cascades) are shown in figure 1. Flood-frequency equations were then developed for each of these regions.

Few gaging-station data for the extreme southern end of the Oregon coast are usable for flood-frequency analysis. Peak-flow and basin-characteristics data for three gaging stations at the extreme northern end of the California coastal area were used to supplement the Oregon coast data. To determine the flood-frequency equations for the Coast Region, data from 37 stations in Oregon and three in California were used in the multiple-regression analysis. 
To develop the flood-frequency equation for the Willamette Region, peak-flow and basin-characteristics data from six stations across the Columbia River in Washington were used to supplement data from 105 stations in Oregon.

Data from 60 Oregon stations in the Rogue-Umpqua Region and from 28 Oregon stations in the High Cascades Region were used to develop the respective regional equations.

The final regression equations for each of the four regions are shown in table 1 . These equations relate floods having exceedance probabilities of $\mathrm{Q}_{0.5}, \mathrm{Q}_{0.2}, \mathrm{Q}_{0.10}$, $\mathrm{Q}_{0.04}, \mathrm{Q}_{0.02}$, and $\mathrm{Q}_{0.01}$ to selected basin characteristics in each of the flood-frequency regions shown in figure 1 . The general form of the equation and the standard error of estimate is also shown in table 1.

Drainage area (A) and precipitation intensity (I) were selected as the most significant independent variables for the flood-frequency equation for the Willamette Region. Drainage area, precipitation intensity, and area of lakes and ponds (ST) were selected as the most significant independent variables for the Coast and Rogue-Umpqua Regions. For the High Cascades Region, drainage area, area of lakes and ponds, precipitation intensity, and nonforested areas proved to be the most significant independent variables to use in the flood-frequency equation. In the frequency equation for the High Cascades Region, nonforested area is expressed as a function of forest cover (F).

Soils index and azimuth were not used in the final regression analysis. These two basin characteristics were not found to be significant in preliminary analysis, which was based strictly on data for Oregon stations.

\section{APPLICATION OF RESULTS}

\section{Method Used}

The design flow or peak discharge for selected exceedance probabilities (or recurrence intervals) can be estimated for sites on unregulated streams in Oregon by using the method described below.

1. Locate the site on the map (pl. 1, in pocket) and determine which region it is in and if it is on a gaged stream.

a. If the site is at a gaging station used in this analysis or is on the same stream as a gaging station used in this analysis and has a drainage area within 5 percent of that at the gaged site, USE THE GAGING-STATION DATA DIRECTLY FROM TABLE 4.

b. If the site is on a stream that has a gaging station listed in this report but has a drainage area estimated at 5 to 25 percent different from that at the gaging station, adjust the peak discharges of the gaged site (table 4) on the basis of drainage area by using the following equation: $Q_{u}=Q_{g}(A u / A g)^{a}$, where $Q_{u}$ and $\mathrm{Q}_{\mathrm{g}}$ are the discharges at the ungaged and gaged sites, $\mathrm{Au}$ and $\mathrm{Ag}$ are the drainage areas, and "a" is an exponent. The value for "a" can be selected from the exponents for the drainage area (A) given in the equation in table 1 .

2. If the site is on an ungaged stream or if the site is on a gaged stream shown in table 4 but the drainage area at the site differs by more than an estimated 25 percent from the drainage area at the gaging station, then

a. Inspect the applicable regional equations in table 1 and identify which basin characteristics are needed to estimate discharge for selected exceedance probabilities. 
Table 1.-Regional flood-frequency equations

General form of equation $\mathrm{QT}_{\mathrm{T}}=\mathrm{KA}^{\mathrm{a}}(\mathrm{ST}+1)^{\mathrm{b}}(101-\mathrm{F})^{\mathrm{c}} \mathrm{I}^{\mathrm{d}}$ where

$\mathrm{Q}_{\mathrm{T}}=$ discharge for selected exceedance probability,

$\mathrm{K}=$ regression constant,

$\mathrm{A}=$ drainage area, in square miles,

ST $=$ area of lakes and ponds, in percent,

$\mathrm{F}=$ forest cover, in percent, and

$\mathrm{I}=$ precipitation intensity, in inches.

(When the functions of $\mathrm{F}$ and ST are not significant, the factors $(\mathrm{ST}+1)^{\mathrm{b}}$ and $(101-\mathrm{F})^{\mathrm{c}}$ are omitted from the equation.)

\begin{tabular}{c|c|c}
\hline $\begin{array}{l}\text { Exceedance } \\
\text { probability } \\
(\mathrm{RI}) \underline{l}\end{array}$ & Equation & $\begin{array}{c}\text { Percent } \\
\text { standard } \\
\text { error }\end{array}$ \\
\hline
\end{tabular}

(1) COAST REGION (40 stations)

\begin{tabular}{llll}
\hline $\mathrm{Q}_{0.5}(2)$ & $=$ & $4.59 \mathrm{~A}^{0.96}(\mathrm{ST}+1)^{-0.45} \mathrm{I}^{1.91}$ & 33 \\
$\mathrm{Q}_{0.2}(5)$ & $=$ & $6.27 \mathrm{~A}^{0.95}(\mathrm{ST}+1)^{-0.45} \mathrm{I}^{1.95}$ & 32 \\
$\mathrm{Q}_{0.1}(10)$ & $=$ & $7.32 \mathrm{~A}^{0.94}(\mathrm{ST}+1)^{-0.45} \mathrm{I}^{1.97}$ & 33 \\
$\mathrm{Q}_{0.04}(25)$ & $=$ & $8.71 \mathrm{~A}^{0.93}(\mathrm{ST}+1)^{-0.45} \mathrm{I}^{1.99}$ & 34 \\
$\mathrm{Q}_{0.02}(50)$ & $=$ & $9.73 \mathrm{~A}^{0.93}(\mathrm{ST}+1)^{-0.44} \mathrm{I}^{2.01}$ & 35 \\
$\mathrm{Q}_{0.01}(100)$ & $=$ & $10.7 \mathrm{~A}^{0.92}(\mathrm{ST}+1)^{-0.44} \mathrm{I}^{2.02}$ & 37 \\
\hline
\end{tabular}

(2) WILLAMETTE REGION (111 stations)

\begin{tabular}{llll}
\hline $\mathrm{Q}_{0.5}(2)$ & $=$ & $8.70 \mathrm{~A}^{0.87} \mathrm{I}^{1.71}$ & 33 \\
$\mathrm{Q}_{0.2}(5)$ & $=$ & $15.6 \mathrm{~A}^{0.88} \mathrm{I}^{1.55}$ & 33 \\
$\mathrm{Q}_{0.1}(10)$ & $=$ & $21.5 \mathrm{~A}^{0.88} \mathrm{I}^{1.46}$ & 33 \\
$\mathrm{Q}_{0.04}(25)$ & $=$ & $30.3 \mathrm{~A}^{0.88} \mathrm{I}^{1.37}$ & 34 \\
$\mathrm{Q}_{0.02}(50)$ & $=$ & $38.0 \mathrm{~A}^{0.88} \mathrm{I}^{1.31}$ & 36 \\
$\mathrm{Q}_{0.01}(100)$ & $=$ & $46.9 \mathrm{~A}^{0.88} \mathrm{I}^{1.25}$ & 37 \\
\hline
\end{tabular}

(3) ROGUE-UMPQUA REGION (60 stations)

\begin{tabular}{llll}
\hline $\mathrm{Q}_{0.5}(2)$ & $=$ & $24.2 \mathrm{~A}^{0.86}(\mathrm{ST}+1)^{-1.16} \mathrm{I}^{1.15}$ & 44 \\
$\mathrm{Q}_{0.2}(5)$ & $=$ & $36.0 \mathrm{~A}^{0.88}(\mathrm{ST}+1)^{-1.25} \mathrm{I}^{1.15}$ & 43 \\
$\mathrm{Q}_{0.1}(10)$ & $=$ & $44.8 \mathrm{~A}^{0.88}(\mathrm{ST}+1)^{-1.28} \mathrm{I}^{1.14}$ & 44 \\
$\mathrm{Q}_{0.04}(25)$ & $=$ & $56.9 \mathrm{~A}^{0.89}(\mathrm{ST}+1)^{-1.31} \mathrm{I}^{1.12}$ & 46 \\
$\mathrm{Q}_{0.02}(50)$ & $=$ & $66.7 \mathrm{~A}^{0.90}(\mathrm{ST}+1)^{-1.33} \mathrm{I}^{1.10}$ & 49 \\
$\mathrm{Q}_{0.01}(100)$ & $=$ & $77.3 \mathrm{~A}^{0.90}(\mathrm{ST}+1)^{-1.34} \mathrm{I}^{1.08}$ & 51 \\
\hline
\end{tabular}

(4) HIGH CASCADES REGION (28 stations)

\begin{tabular}{llll}
\hline $\mathrm{Q}_{0.5}(2)$ & $=$ & $4.75 \mathrm{~A}^{0.90}(\mathrm{ST}+1)^{-0.62}(101-\mathrm{F})^{0.11} \mathrm{I}^{1.17}$ & 55 \\
$\mathrm{Q}_{0.2}(5)$ & $=$ & $8.36 \mathrm{~A}^{0.86}(\mathrm{ST}+1)^{-0.81}(101-\mathrm{F})^{0.08} \mathrm{I}^{1.30}$ & 50 \\
$\mathrm{Q}_{0.1}(10)$ & $=$ & $11.3 \mathrm{~A}^{0.85}(\mathrm{ST}+1)^{-0.92}(101-\mathrm{F})^{0.07} \mathrm{I}^{1.37}$ & 53 \\
$\mathrm{Q}_{0.04}(25)$ & $=$ & $15.4 \mathrm{~A}^{0.83}(\mathrm{ST}+1)^{-1.03}(101-\mathrm{F})^{0.05} \mathrm{I}^{1.46}$ & 59 \\
$\mathrm{Q}_{0.02}(50)$ & $=$ & $18.8 \mathrm{~A}^{0.82}(\mathrm{ST}+1)^{-1.10}(101-\mathrm{F})^{0.04} \mathrm{I}^{1.52}$ & 66 \\
$\mathrm{Q}_{0.01}(100)$ & $=$ & $22.6 \mathrm{~A}^{0.81}(\mathrm{ST}+1)^{-1.17}(101-\mathrm{F})^{0.03} \mathrm{I}^{1.57}$ & 72 \\
\hline
\end{tabular}

1) Numbers in parentheses refer to recurrence intervals in years. 
b. Determine the appropriate basin-characteristic values as follows:

Drainage area (A) - Compute the drainage area, in square miles, within the surface-water divide upstream from the desired site on the stream, using the best available topographic map, generally U.S. Geological Survey $71 / 2-$ or 15 minute quadrangle maps. Determine the drainage area by planimetering.

Area of lakes and ponds (ST) - Compute the percentage of the total drainage area occupied by lakes and ponds, using a planimeter or a transparent grid overlay on $7 \frac{1}{2}-$ or 15 -minute topographic maps. In the equation, the value $(\mathrm{ST}+1)$ is used to avoid introducing zero values that cannot be accommodated in the equations used in this study.

Forest-cover index (F) - Compute the percentage of the total drainage area covered by brush or trees, as indicated by the extent of green overprint (vegetation) shown on U.S. Geological Survey topographic maps.

The value of $101-\mathrm{F}$ is used in the equation for the High Cascades Region to reflect the percentage of "nonforest" cover. The value 101 is used rather than 100 to avoid having to deal with the logarithm of zero values. The use of nonforest cover rather than forest cover provided the most practical equation fit.

Precipitation intensity (I) - Determine the maximum 2-year, 24-hour precipitation, in inches, on plate 2 of this report by using the grid method as described under drainage-basin characteristics section for mean basin elevation on page 11 .

c. Compute the peak discharge for the desired exceedance probabilities, or recurrence intervals, directly through the use of the appropriate regional equations.

d. Compare, for reasonableness, the estimated peak discharge values particularly those for small probabilities (long recurrence intervals) with (1) maximum peak discharges for nearby streams (table 3 at the back of the report) and (2) other maximum observed discharges (fig. 2).

Peak discharges for exceedance probabilities between 0.5 and 0.01 , other than those shown in the equations, can be determined either by plotting station values from table 4 or by plotting computed values from the equations on probability paper and drawing a smooth curve through the points. Peak discharges for other exceedance probabilities can then be estimated from the curve.

Extrapolation of peak discharges for exceedance probabilities greater than 0.01 (the 100-year flood) exceeds the limits of this study. Such derived values should be qualified and used judiciously.

\section{Evaluation of Estimates}

Peak discharges estimated from the regression equation can be evaluated for credibility by comparison to maximum observed peak discharges for streams with similar drainage areas in the same regions. Maximum observed peak discharges for all gaging stations used in the analysis are listed in table 3. Figure 2 shows the maximum observed peak discharges for long-term gaging stations in western Oregon in relation to drainage area. Figure 2 also shows a maximum envelope curve developed by Mat thai (1969). For drainage areas between 1 and $200 \mathrm{mi}^{2}$, the equation for the Matthai curve is $\mathrm{Q}=11,000 \mathrm{~A}^{0.61}$. Also shown are the observed discharges that have the highest unit runoff measured in 
Oregon and the highest peak discharges observed throughout the United States. Figure 2 can be used to judge the reasonableness or uniqueness of flood-peak discharges estimated by use of flood-frequency equations. For example, if the 0.02 (50-year) flood discharge estimated for a site with a drainage area of $10 \mathrm{mi}^{2}$ was $10,000 \mathrm{ft}^{3} / \mathrm{s}$, a comparison with figure 2 indicates the discharge could be too high for western Oregon. The user might then check the computations and also decide that the regional equations are not applicable if the basin being studied is not typical of the region.

On some streams the geology of the drainage basin can have a large effect on the magnitude of the flood peak. An example is the Clearwater River above Trap Creek near Toketee Falls (14314500) in the Umpqua River basin. Most of the Trap Creek drainage is located in a geologic area of recent volcanics (Wells and Peck, 1961). Observed flood peaks at the Clearwater River above Trap Creek gaging station are much smaller in magnitude than are indicated by the regional equation. It appears that

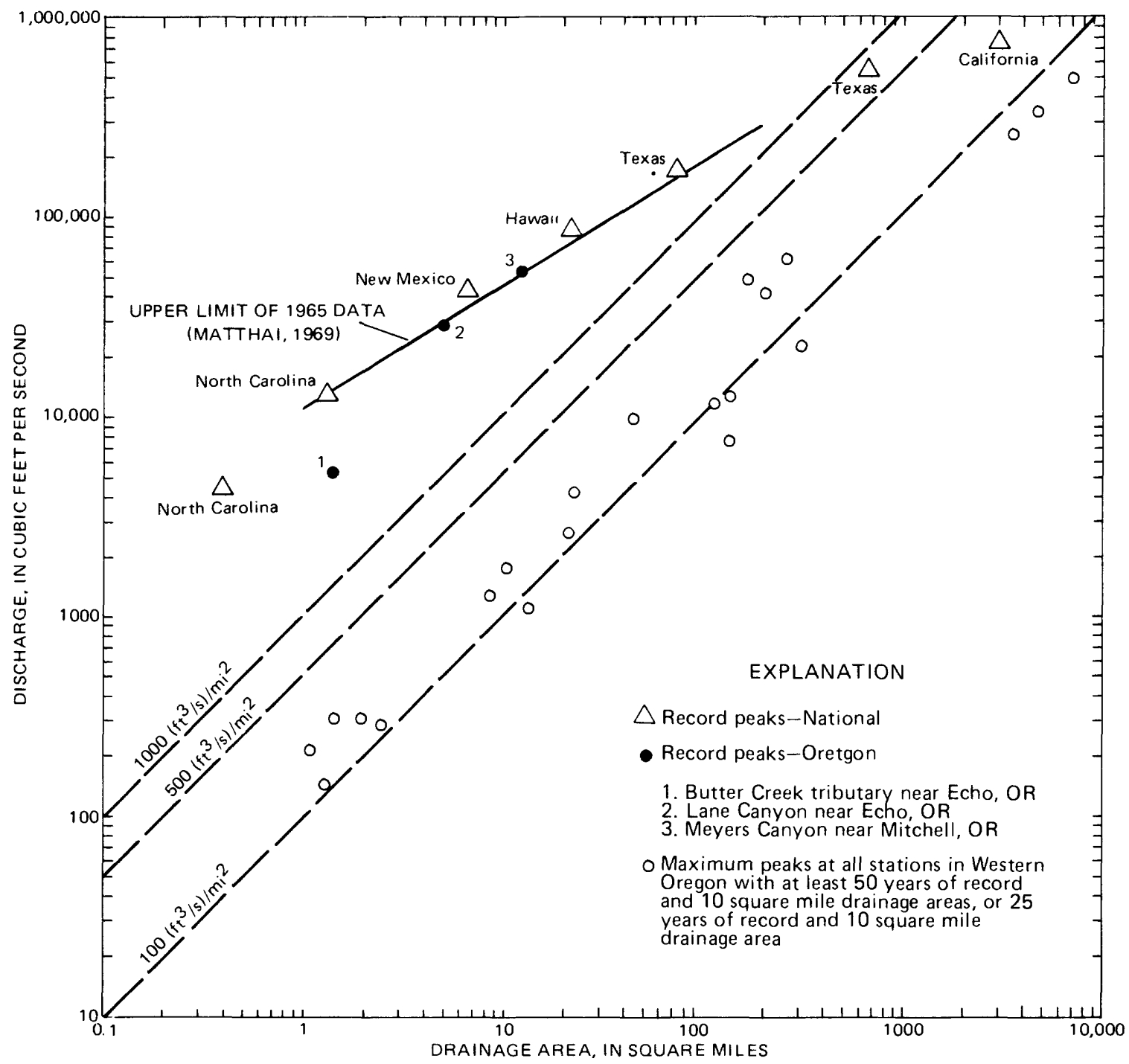

Figure 2.-Maximum observed peak discharges in relation to drainage areas. 
peaks at this gaging station are greatly diminished because of temporary ground-water storage. Numerous springs along the Clearwater River above Trap Creek tend to support this assumption. Other streams in similar recent volcanic geology will probably respond in the same manner. Therefore, the geology map should be consulted to evaluate the possibility of the actual flood peaks differing from those indicated by the regional equation because of the local geology.

Some of the older peak discharges used in this analysis were based on once or twice daily gage readings which may be lower than the actual instantaneous peak and therefore would not represent the highest discharge during the day. The effect of such peaks on the analysis has not been thoroughly evaluated; however, because only about 2 percent of the peaks were determined in this manner, their use likely has little influence on the resulting equations.

Weather stations are sparsely located in the High Cascades Region; therefore, the precipitation intensity values shown on plate 2 are probably somewhat less reliable for the High Cascades than for the other three flood-frequency regions, where there are more precipitation gages. This lack of basic precipitation data probably contributed to the higher standard error for the High Cascades Region. This higher standard error may also be attributed to the lack of regional snowpack information. No basin characteristics for snowpack were available for the regression analysis; however, it would be reasonable to assume that snowpack would influence the flood-frequency equations for the High Cascades.

\section{Illustrative Problems}

The method for estimating discharges of selected recurrence intervals is shown by the following examples:

Example 1. (Determining a single flood in an ungaged area)

Determine the discharge for an exceedance probability of 0.01 (100-year flood) for a site in the Coast Region, where the drainage area is $20 \mathrm{mi}^{2}$ and the area of lakes and ponds is 1.2 percent of the drainage area. According to the precipitation intensity map (pl. 2, in pocket), the site is at a location where the average 2-year, 24-hour precipitation intensity over the drainage basin is $4.0 \mathrm{in}$.

From the Coast Region equation (see table 1), the 0.01 exceedance probability flood is:

$$
\begin{aligned}
\mathrm{Q}_{0.01} & =10.7 \mathrm{~A}^{0.92}(\mathrm{ST}+1)^{-0.44} \mathrm{I}^{2.02} \\
& =(10.7)(20)^{0.92}(2.2)^{-0.44}(4)^{2.02} \\
& =\frac{(10.7)(15.7)(16.4)}{(1.41)} \\
& =1,950 \mathrm{ft}^{3} / \mathrm{s}
\end{aligned}
$$

Example 2. (Determining two floods in an ungaged area)

Determine the discharge for exceedance probabilities of 0.5 and 0.1 (2- and 10-year floods) for a site on a stream in the High Cascades Region. The drainage area is $9.8 \mathrm{mi}^{2}$; the area of lakes and ponds (ST) is 2.5 percent; forest cover (F) is 96 percent; and the average 2-year, 24-hour precipitation intensity is $3.2 \mathrm{in}$.

From the High Cascades Region equation, the 0.5 exceedance probability flood is:

$$
\begin{aligned}
\mathrm{Q}_{0.5} & =4.75 \mathrm{~A}^{0.90}(\mathrm{ST}+1)^{-0.62}(101-\mathrm{F})^{0.11} \mathrm{I}^{1.17} \\
& =4.75(9.8)^{0.90}(2.5+1)^{-0.62}(101-96)^{0.11}(3.2)^{1.17} \\
& =(4.75)(7.80)(0.46)(1.19)(3.90) \\
& =79 \mathrm{ft}^{3} / \mathrm{s}
\end{aligned}
$$


From the High Cascades Region equation, the 0.1 exceedance probability flood is:

$$
\begin{aligned}
\mathrm{Q}_{0.1} & =11.3(\mathrm{~A})^{0.85}(\mathrm{ST}+1)^{-0.92}(101-\mathrm{F})^{0.07} \mathrm{I}^{1.37} \\
& =11.3(9.8)^{0.85}(2.5+1)^{-0.92}(101-96)^{0.07}(3.2)^{1.37} \\
& =11.3(6.96)(0.32)(1.12)(4.92) \\
& =139 \mathrm{ft}^{3} / \mathrm{s}
\end{aligned}
$$

Example 3. (Developing a flood-frequency curve)

Develop a flood-frequency curve for a site in the Willamette Region. The drainage area is $230 \mathrm{mi}^{2}$; and the average 2-year, 24-hour precipitation intensity is $3.1 \mathrm{in}$.

Based on the above basin characteristics, develop a flood-frequency curve by computing the flood discharges for $\mathrm{Q}_{0.5}, \mathrm{Q}_{0.2}, \mathrm{Q}_{0.1}, \mathrm{Q}_{0.4}, \mathrm{Q}_{0.02}$, and $\mathrm{Q}_{0.01}$ exceedance probabilities, as shown below:

$$
\begin{aligned}
\mathrm{Q}_{0.5} & =8.70(\mathrm{~A})^{0.87}(\mathrm{I})^{1.71} \\
& =8.70(230)^{0.87}(3.1)^{1.71} \\
& =(8.70)(113)(6.92) \\
& =6,800 \mathrm{ft}^{3} / \mathrm{s} \\
\mathrm{Q}_{0.2} & =15.6(\mathrm{~A})^{0.88}(\mathrm{I})^{1.55} \\
& =15.6(230)^{0.88}(3.1)^{1.55} \\
& =(15.6)(120)(5.78) \\
& =10,800 \mathrm{ft}^{3} / \mathrm{s} \\
\mathrm{Q}_{0.1} & =21.5(\mathrm{~A})^{0.88}(\mathrm{I})^{1.46} \\
& =21.5(230)^{0.88}(3.1)^{1.46} \\
& =(21.5)(120)(5.22) \\
& =13,500 \mathrm{ft}^{3} / \mathrm{s} \\
\mathrm{Q}_{0.04} & =30.3(\mathrm{~A})^{0.88}(\mathrm{I})^{1.37} \\
& =30.3(230)^{0.88}(3.1)^{1.37} \\
& =(30.3)(120)(4.71) \\
& =17,100 \mathrm{ft}^{3} / \mathrm{s} \\
\mathrm{Q}_{0.01} & =46.9(\mathrm{~A})^{0.88}(\mathrm{I})^{1.25} \\
& =46.9(230)^{0.88}(3.1)^{1.25} \\
& =(46.9)(120)(4.11) \\
& =23,100 \mathrm{ft}^{3} / \mathrm{s} \\
& =38.0(\mathrm{~A})^{0.88}(\mathrm{I})^{1.31} \\
& =38.0(230)^{0.88}(3.1)^{1.31} \\
& =(38.0)(120)(4.40) \\
& =20,100 \mathrm{ft}^{3} / \mathrm{s} \\
&
\end{aligned}
$$


Then plot the flood discharges on probability paper at the respective exceedance positions and draw a smooth curve through the points, as shown in figure 3.

Example 4. (Determining the exceedance probability or recurrence interval for a selected discharge)

Using the curve developed in example 3 (fig. 3 ), determine the exceedance probability and recurrence interval for a peak discharge of $16,000 \mathrm{ft}^{3} / \mathrm{s}$.

At the $16,000-\mathrm{ft}^{3} / \mathrm{s}$ discharge magnitude on the graph, project horizontally to the frequency curve. Project up vertically at the intersection with the curve and read an exceedance probability of 0.05 and project down vertically and read a recurrence interval of 20 years.

\section{EXCEEDANCE PROBABILITY}

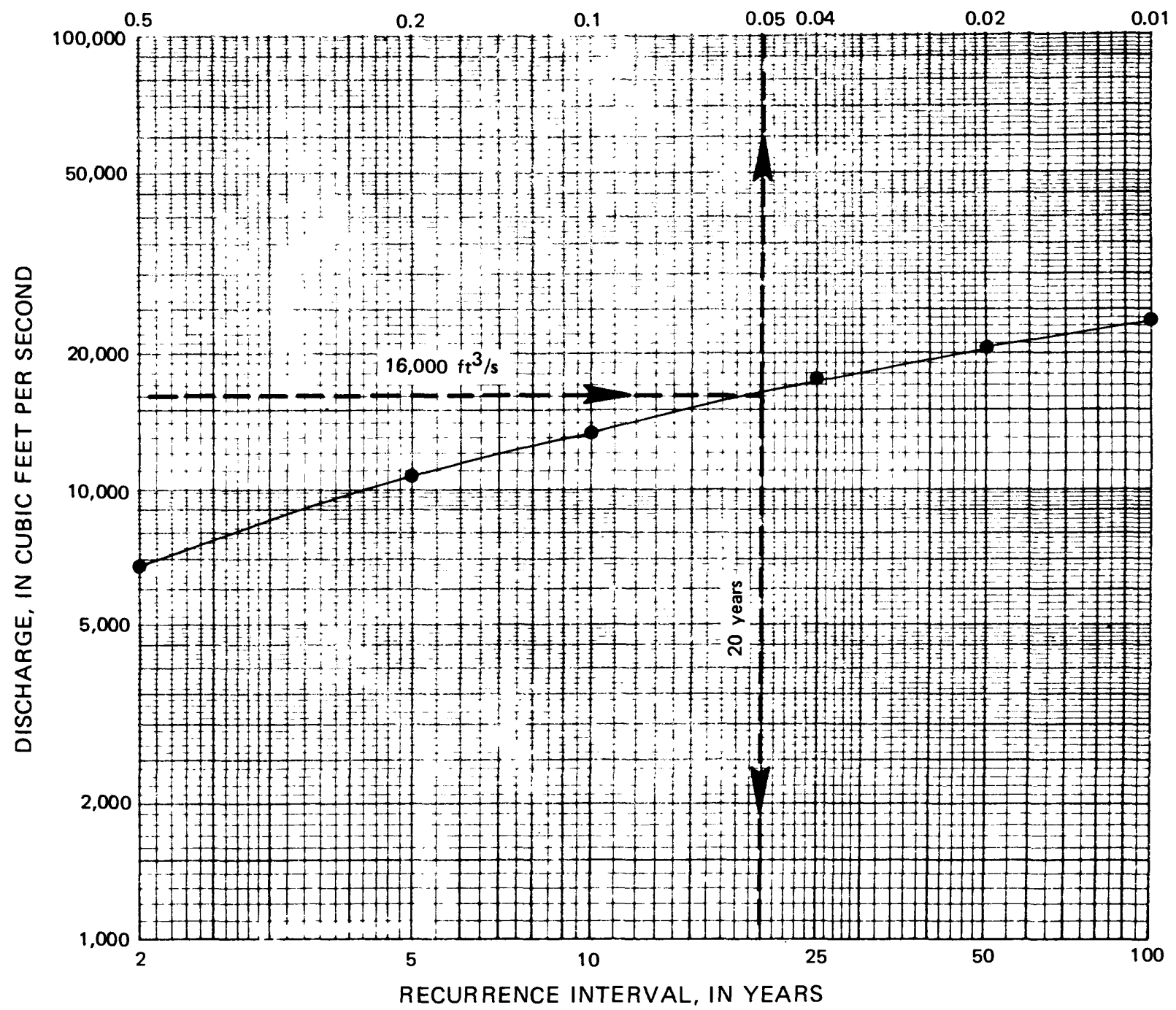

Figure 3.-Flood-frequency curve developed by regional analysis for an example computation at an ungaged site in the Willamette Region (example 3). 
Example 5. (Determining a flood on a stream near an existing gaging station)

Determine the discharge for an exceedance probability of 0.01 (the 100-year flood) for a site upstream from the existing long-term gaging station on Salmon Creek near Oakridge (No. 1414650) in the Willamette Region. The gaged site has a drainage area of $117 \mathrm{mi}^{2}$, and the selected site has a drainage area of $100 \mathrm{mi}^{2}$. Therefore, the drainage areas differ by more than 5 percent but less than 25 percent. The flood for an exceedance probability of 0.01 at the gaged site (table 4) is $14,000 \mathrm{ft}^{3} / \mathrm{s}$. Use the relationship $\mathrm{Q}_{\mathrm{u}}=\mathrm{Q}_{\mathrm{g}}(\mathrm{Au} / \mathrm{Ag})^{\mathrm{a}}$. The exponent " $\mathrm{a}$ " for an exceedance probability of 0.01 in the Willamette Region is 0.88 .

$$
\begin{aligned}
Q_{u} & =Q_{g}(A u / A g)^{b} \\
& =14,000\left(\frac{100}{117}\right)^{0.88} \\
& =(14,000)(0.85)^{0.88} \\
& =(14,000)(0.87) \\
& =12,200 \mathrm{ft}^{3} / \mathrm{s}
\end{aligned}
$$

\section{Limitations}

The equations in this report, developed through regional analysis, are usable, under certain limitations, for estimating flood magnitudes of selected exceedance probabilities or recurrence intervals at ungaged sites in western Oregon.

The equations are based on data representing natural flood conditions and are not applicable to streams where storage or artificial structures have modified the flow appreciably such as sites downstream from large storage reservoirs. In general, the equations are not applicable at any site where flow from 10 percent or more of the drainage basin is controlled.

Ranges of characteristics used for defining equations for each region are:

\begin{tabular}{l|c|c|c|c}
\hline Region & $\begin{array}{c}\text { Drainage } \\
\text { area } \\
(\mathrm{A}) \\
\left(\mathrm{mi}^{2}\right)\end{array}$ & $\begin{array}{c}\text { Area of } \\
\text { lakes and } \\
\text { ponds } \\
\text { (ST) } \\
\text { (percent) }\end{array}$ & $\begin{array}{c}\text { Forest } \\
\text { cover } \\
\text { (F) } \\
\text { (percent) }\end{array}$ & $\begin{array}{c}\text { Precipitation } \\
\text { intensity } \\
\text { (I) } \\
\text { (in.) }\end{array}$ \\
\hline 1. Coast & $0.27-667$ & $0-18.81$ & -- & $3.0-6.2$ \\
2. Willamette & $0.37-7,280$ & -- & -- & $2.3-5.0$ \\
3. Rogue-Umpqua & $0.75-3,939$ & $0-4.40$ & -- & $2.5-6.2$ \\
4. High Cascades & $0.21-650$ & $0-3.65$ & $48-100$ & $1.4-4.3$ \\
\hline
\end{tabular}

Extrapolation beyond the limits of the data used for defining relationships is not advisable. Such extrapolations could produce erroneous discharge values. However, if extrapolations are made they should be used judiciously and qualified accordingly. 


\section{SUMMARY}

The study describes a method for estimating the magnitude and frequency of floods on natural streams in western Oregon. The equations were developed by regional multipleregression analysis. An evaluation of the differences between the flood discharges estimated from the gaging-station records and the discharges determined from the general regression equation were used to help delineate boundaries for four flood-frequency regions in western Oregon.

Drainage-area size was the most significant basin characteristic for all four of the floodfrequency regions in western Oregon. Precipitation intensity was also a significant basin characteristic for all the regions. By utilizing only the drainage-area size and precipitation intensity for the Willamette Region, the standard error of estimate ranged from 33 to 37 percent, as shown in table 1. The area of lakes and ponds was used in addition to drainagearea size and precipitation intensity in the flood-frequency equation for the Coast and RogueUmpqua Regions. The standard error of estimate ranged from 32 to 37 percent in the Coast Region and from 43 to 51 percent in the Rogue-Umpqua Region.

The standard errors of estimate were greatest in the High Cascades Region, where the range was 50 to 72 percent. Four basin characteristics (drainage area, precipitation intensity, area of lakes and ponds, and forest cover) were required to reduce the standard error significantly in this region.

When used within the range of data used to define the relationships, the regional floodfrequency equations provide reasonably accurate estimates of floodflows of specified exceedance probabilities. 


\section{SELECTED REFERENCES}

Benson, M. A., 1962a, Evolution of methods for evaluating the occurrence of floods: U.S. Geological Survey Water-Supply Paper 1580-A, 29 p. $1962 \mathrm{~b}$, Factors influencing the occurrence of floods in a humid region of diverse terrain: U.S. Geological Survey Water-Supply Paper 1580-B, 64 p.

1964, Factors affecting the occurrence of floods in the Southwest: U.S. Geological Survey Water-Supply Paper 1580-D, $72 \mathrm{p}$.

Columbia Basin Inter-Agency Committee, 1963, River mile index-Willamette River, Columbia River basin, Oregon: Hydrology Subcommittee report, $57 \mathrm{p}$. 1966, River mile index - Umpqua River and tributaries, Umpqua River basin, Oregon: Hydrology Subcommittee report, $25 \mathrm{p}$.

1967, River mile index - Rogue River, Pacific slope basin, Oregon: Hydrology Subcommittee report, $28 \mathrm{p}$.

Friday, John, 1974, Crest-stage gaging stations in Oregon, A compilation of peak data collected from October 1952 to September 1974: U.S. Geological Survey open-file report, $160 \mathrm{p}$.

Hardison, C. H., 1971, Prediction error of regression estimates of streamflow characteristics at ungaged sites, in Geological Survey Research, 1971: U.S. Geological Survey Professional Paper 750-C, p. C228-C236.

Hulsing, Harry, and Kallio, N. A., 1964, Pacific slope basins in Oregon and lower Columbia River basin, part 14 of Magnitude and frequency of floods in the United States: U.S. Geological Survey Water-Supply Paper 1689, 320 p.

Lystrom, D. J., 1970, Evaluation of the streamflow-data program in Oregon: U.S. Geological Survey open-file report, $28 \mathrm{p}$.

Matthai, H. F., 1969, Floods of June 1965 in South Platte River basin, Colorado: U.S. Geological Survey Water-Supply Paper 1850-B, 64 p.

Pacific Northwest River Basins Commission, 1968, River mile index - Coastal tributaries, Pacific coast basin, Oregon: Hydrology and Hydraulics Committee report, $84 \mathrm{p}$.

Riggs, H. C., 1968, Some statistical tools in hydrology: U.S. Geological Survey Techniques of Water-Resources Investigations, book 4, chap. A1, 39 p.

1968, Frequency curves: U.S. Geological Survey Techniques of Water-Resources Investigations, book 4, chap. A2, 15 p.

1973, Regional analyses of streamflow characteristics: U.S. Geological Survey Techniques of Water-Resources Investigations, book 4, chap. B3, 15 p.

Sternes, G. L., 1960, Climates of the States, Oregon, in Climatography of the United States: U.S. Weather Bureau, no. 60-35, p. 17.

Thomas, D. M., and Benson, M. A., 1970, Generalization of streamflow characteristics from drainage-basin characteristics: U.S. Geological Survey Water-Supply Paper 1975, 55 p.

U.S. Dept. of Agriculture, Soil Conservation Service, 1959, State engineering handbook, Oregon, sec. 4 in Hydrology: $10 \mathrm{p}$.

1964, Watershed planning, pt. 1 in Watershed planning, sec. 4 in Hydrology: U.S. Dept. Agriculture SCS Handb.

U.S. National Oceanic and Atmospheric Administration, 1965, Climates of the States-Washington, of Climatology of the United States no. 60-45: Washington, D. C., 27 p.

1973, Precipitation-frequency atlas of the Western United States, NOAA Atlas 2, volume X - Oregon: Silver Spring, Md., 43 p.

U.S. Water Resources Council, 1967 [rev. 1977], A uniform technique for determining flood flow frequencies: Washington, D. C., U.S. Water Resources Council Bulletin 15, 15 p. 1977, Guidelines for determining flood flow frequency: Washington, D.C., Water Resources Council Bulletin 17A, 26 p.

U.S. Weather Bureau, 1964, Mean annual precipitation, 1930-57, State of Oregon: Portland, Oreg., U.S. Soil Conservation Service Map M-4161.

Wells, F. G., and Peck, D. L., 1961, Geologic map of Oregon west of the 121st meridian: U.S. Geological Survey Miscellaneous Investigations Map I-325, scale 1:500,000. 
Table 2.-Basin characteristics used in multuple regressions

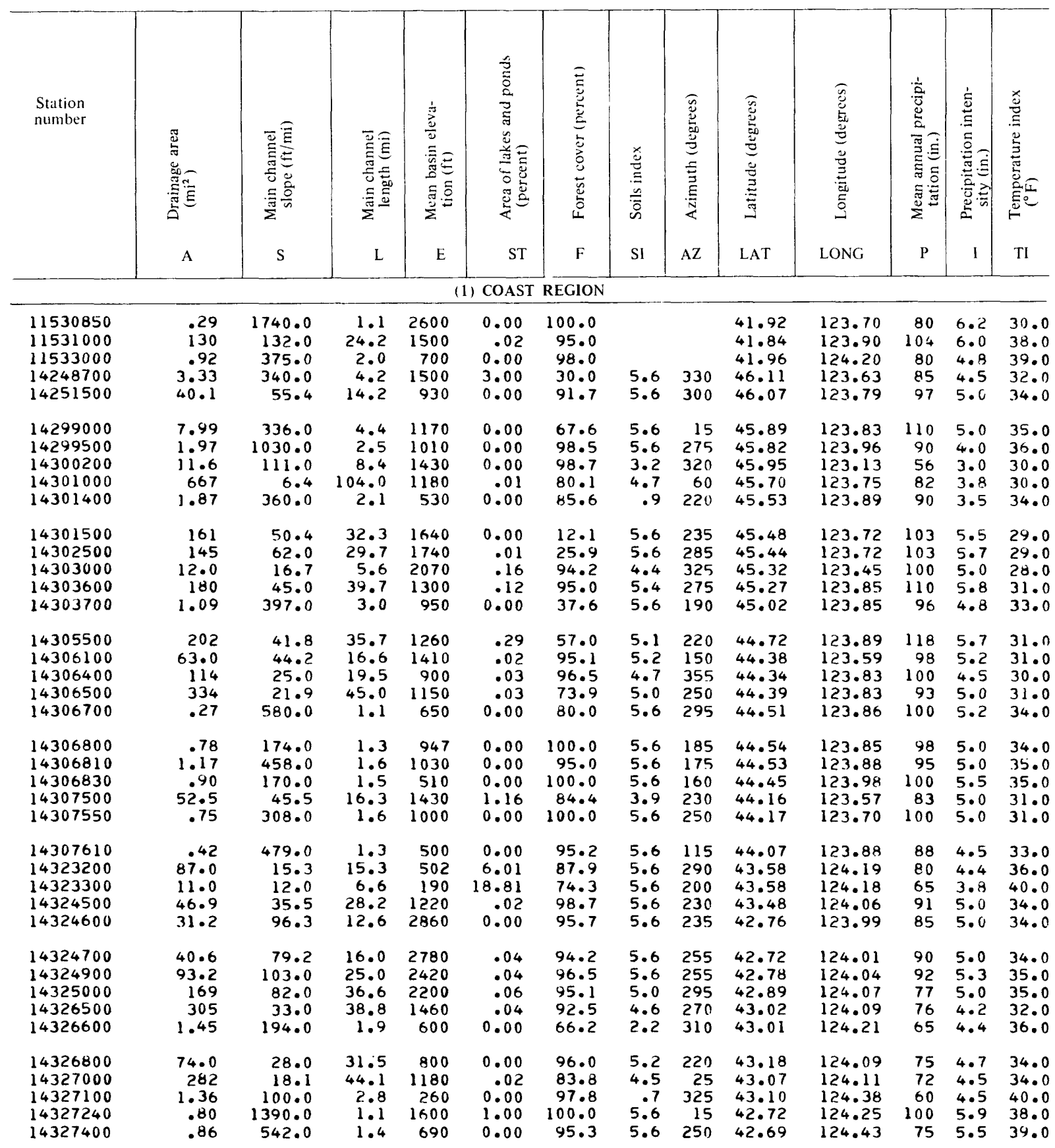


Table 2.-Basin characteristics used in multiple regressions-continued

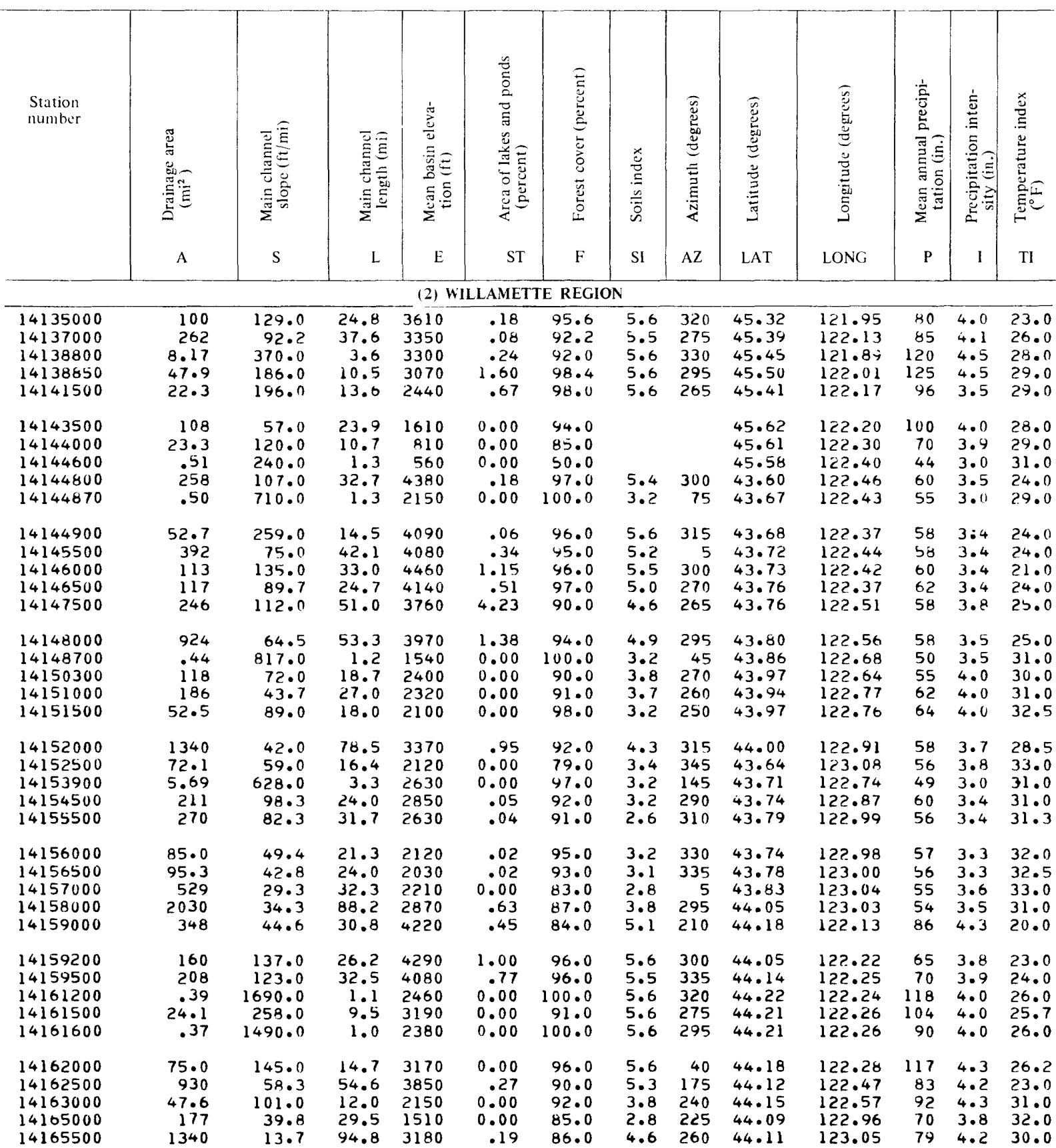


Table 2.-Basin characteristics used in multiple regressions-continued

\begin{tabular}{|c|c|c|c|c|c|c|c|c|c|c|c|c|c|}
\hline $\begin{array}{l}\text { Station } \\
\text { number }\end{array}$ & 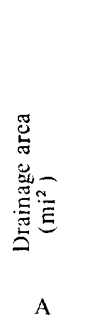 & 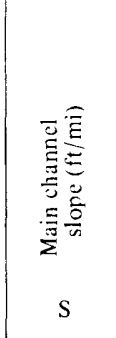 & 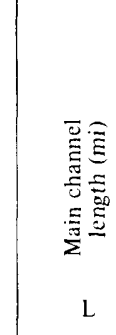 & 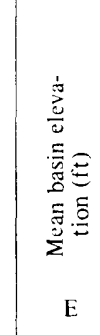 & 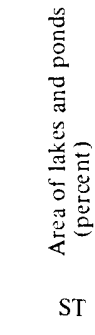 & 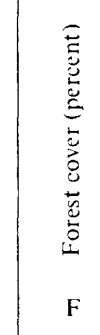 & $\begin{array}{l}\stackrel{x}{\stackrel{\Xi}{\Xi}} \\
\stackrel{n}{\overline{0}} \\
\text { SI }\end{array}$ & 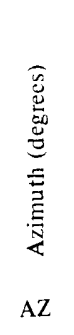 & 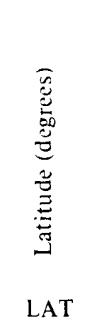 & 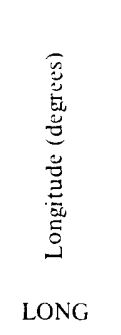 & 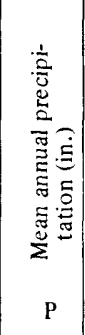 & 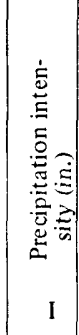 & 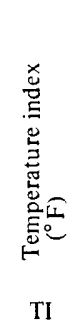 \\
\hline \multicolumn{14}{|c|}{ (2) WILLAMETTE REGION } \\
\hline $\begin{array}{l}14166500 \\
14167000 \\
14169700 \\
14170500 \\
14171000\end{array}$ & $\begin{array}{r}89.3 \\
95.1 \\
5.19 \\
14.6 \\
159\end{array}$ & $\begin{array}{r}13.1 \\
10.9 \\
67.5 \\
277.0 \\
13.4\end{array}$ & $\begin{array}{r}18.3 \\
23.3 \\
5.3 \\
7.8 \\
37.7\end{array}$ & $\begin{array}{r}740 \\
730 \\
857 \\
1510 \\
925\end{array}$ & $\begin{array}{l}.07 \\
0.00 \\
0.00 \\
0.00 \\
0.00\end{array}$ & $\begin{array}{r}78.0 \\
60.0 \\
54.0 \\
100.0 \\
82.0\end{array}$ & $\begin{array}{l}1.9 \\
1.7 \\
1.2 \\
3.2 \\
1.9\end{array}$ & $\begin{array}{l}15 \\
340 \\
140 \\
110 \\
315\end{array}$ & $\begin{array}{l}44.05 \\
44.02 \\
44.16 \\
44.50 \\
44.53\end{array}$ & $\begin{array}{l}123.42 \\
123.25 \\
123.35 \\
123.44 \\
123.33\end{array}$ & $\begin{array}{l}67 \\
43 \\
48 \\
91 \\
78\end{array}$ & $\begin{array}{l}3.6 \\
3.2 \\
3.5 \\
3.8 \\
4.0\end{array}$ & $\begin{array}{l}31.0 \\
32.5 \\
32.0 \\
31.0 \\
31.0\end{array}$ \\
\hline $\begin{array}{l}14171500 \\
14172000 \\
14172300 \\
14173500 \\
14174000\end{array}$ & $\begin{array}{r}107 \\
105 \\
5.06 \\
372 \\
4840\end{array}$ & $\begin{array}{r}4.0 \\
64.6 \\
221.0 \\
21.1 \\
18.8\end{array}$ & $\begin{array}{r}22.8 \\
30.5 \\
4.1 \\
72.9 \\
154.0\end{array}$ & $\begin{array}{r}630 \\
2060 \\
877 \\
955 \\
2230\end{array}$ & $\begin{array}{l}.03 \\
0.00 \\
0.00 \\
0.00 \\
.03\end{array}$ & $\begin{array}{l}42.0 \\
87.0 \\
59.0 \\
31.0 \\
71.0\end{array}$ & $\begin{array}{r}1.0 \\
4.3 \\
.8 \\
1.9 \\
3.1\end{array}$ & $\begin{array}{r}15 \\
295 \\
305 \\
300 \\
330\end{array}$ & $\begin{array}{l}44.50 \\
44.35 \\
44.47 \\
44.62 \\
44.64\end{array}$ & $\begin{array}{l}123.33 \\
122.79 \\
122.96 \\
123.13 \\
123.11\end{array}$ & $\begin{array}{l}50 \\
89 \\
50 \\
56 \\
60\end{array}$ & $\begin{array}{l}3.5 \\
4.2 \\
2.9 \\
3.3 \\
3.6\end{array}$ & $\begin{array}{l}32.0 \\
31.0 \\
33.0 \\
33.0 \\
31.0\end{array}$ \\
\hline $\begin{array}{l}14174100 \\
14178000 \\
14178800 \\
14179000 \\
14181500\end{array}$ & $\begin{array}{r}15.2 \\
216 \\
1.03 \\
106 \\
453\end{array}$ & $\begin{array}{r}10.5 \\
93.3 \\
1420.0 \\
180.0 \\
66.3\end{array}$ & $\begin{array}{l}15.5 \\
35.7 \\
1.5 \\
21.8 \\
49.1\end{array}$ & $\begin{array}{r}261 \\
3720 \\
3010 \\
3720 \\
3510\end{array}$ & $\begin{array}{r}.30 \\
.60 \\
0.00 \\
.19 \\
.33\end{array}$ & $\begin{array}{r}0.0 \\
92.0 \\
100.0 \\
91.5 \\
90.0\end{array}$ & $\begin{array}{l}.9 \\
5.4 \\
5.6 \\
5.5 \\
5.6\end{array}$ & $\begin{array}{l}320 \\
160 \\
340 \\
270 \\
315\end{array}$ & $\begin{array}{l}44.64 \\
44.71 \\
44.76 \\
44.75 \\
44.75\end{array}$ & $\begin{array}{l}123.07 \\
122.10 \\
122.12 \\
122.13 \\
122.30\end{array}$ & $\begin{array}{l}42 \\
80 \\
77 \\
77 \\
81\end{array}$ & $\begin{array}{l}2.5 \\
4.1 \\
3.5 \\
3.7 \\
4.2\end{array}$ & $\begin{array}{l}33.0 \\
20.0 \\
21.0 \\
23.0 \\
22.0\end{array}$ \\
\hline $\begin{array}{l}14181700 \\
14182500 \\
14183000 \\
14184900 \\
14185000\end{array}$ & $\begin{array}{r}.41 \\
112 \\
655 \\
1.35 \\
174\end{array}$ & $\begin{array}{r}529.0 \\
77.4 \\
53.3 \\
714.0 \\
102.0\end{array}$ & $\begin{array}{r}1.4 \\
29.5 \\
68.5 \\
1.9 \\
23.5\end{array}$ & $\begin{array}{l}1440 \\
2640 \\
3350 \\
1780 \\
2870\end{array}$ & $\begin{array}{r}0.00 \\
.36 \\
.24 \\
0.00 \\
.03\end{array}$ & $\begin{array}{r}100.0 \\
95.0 \\
89.6 \\
100.0 \\
92.0\end{array}$ & $\begin{array}{l}1.2 \\
4.5 \\
5.0 \\
3.2 \\
5.5\end{array}$ & $\begin{array}{r}190 \\
255 \\
305 \\
10 \\
280\end{array}$ & $\begin{array}{l}44.75 \\
44.79 \\
44.79 \\
44.39 \\
44.39\end{array}$ & $\begin{array}{l}122.39 \\
122.58 \\
122.62 \\
122.51 \\
122.51\end{array}$ & $\begin{array}{r}69 \\
97 \\
86 \\
68 \\
101\end{array}$ & $\begin{array}{l}4.0 \\
4.4 \\
4.1 \\
3.4 \\
4.7\end{array}$ & $\begin{array}{l}26.5 \\
27.0 \\
27.0 \\
28.0 \\
27.0\end{array}$ \\
\hline $\begin{array}{l}14185800 \\
14185900 \\
14186000 \\
14187000 \\
14187500\end{array}$ & $\begin{array}{r}104 \\
99.2 \\
271 \\
51.8 \\
640\end{array}$ & $\begin{array}{r}100.0 \\
107.0 \\
71.6 \\
129.0 \\
35.7\end{array}$ & $\begin{array}{l}22.0 \\
21.2 \\
32.4 \\
13.6 \\
49.4\end{array}$ & $\begin{array}{l}3300 \\
3200 \\
2970 \\
2480 \\
2560\end{array}$ & $\begin{array}{r}.30 \\
0.00 \\
.02 \\
0.00 \\
.02\end{array}$ & $\begin{array}{r}100.0 \\
100.0 \\
96.0 \\
83.0 \\
86.0\end{array}$ & $\begin{array}{l}5.6 \\
5.6 \\
5.2 \\
4.7 \\
4.5\end{array}$ & $\begin{array}{l}300 \\
265 \\
275 \\
305 \\
285\end{array}$ & $\begin{array}{l}44.52 \\
44.54 \\
44.46 \\
44.37 \\
44.50\end{array}$ & $\begin{array}{l}122.37 \\
122.43 \\
122.52 \\
122.62 \\
122.82\end{array}$ & $\begin{array}{r}110 \\
110 \\
106 \\
71 \\
90\end{array}$ & $\begin{array}{l}5.0 \\
5.0 \\
4.7 \\
3.9 \\
4.3\end{array}$ & $\begin{array}{l}28.0 \\
24.0 \\
26.0 \\
30.0 \\
28.0\end{array}$ \\
\hline $\begin{array}{l}14188800 \\
14189000 \\
14189500 \\
14190000 \\
14190200\end{array}$ & $\begin{array}{r}109 \\
1790 \\
34.3 \\
115 \\
3.46\end{array}$ & $\begin{array}{r}88.0 \\
36.2 \\
115.0 \\
39.5 \\
138.0\end{array}$ & $\begin{array}{r}27.0 \\
96.8 \\
15.2 \\
28.7 \\
3.7\end{array}$ & $\begin{array}{r}1900 \\
2470 \\
1310 \\
1010 \\
874\end{array}$ & $\begin{array}{l}.03 \\
.09 \\
0.00 \\
0.00 \\
0.00\end{array}$ & $\begin{array}{l}90.0 \\
78.0 \\
95.0 \\
89.0 \\
83.0\end{array}$ & $\begin{array}{r}3.3 \\
4.0 \\
3.3 \\
1.8 \\
.6\end{array}$ & $\begin{array}{r}285 \\
290 \\
55 \\
135 \\
35\end{array}$ & $\begin{array}{l}44.71 \\
44.72 \\
44.72 \\
44.74 \\
44.87\end{array}$ & $\begin{array}{l}122.77 \\
123.01 \\
123.50 \\
123.42 \\
123.41\end{array}$ & $\begin{array}{l}55 \\
78 \\
91 \\
74 \\
80\end{array}$ & $\begin{array}{l}3.5 \\
3.9 \\
4.6 \\
4.3 \\
4.2\end{array}$ & $\begin{array}{l}28.0 \\
27.0 \\
30.0 \\
30.0 \\
30.0\end{array}$ \\
\hline $\begin{array}{l}14190500 \\
14190600 \\
14191000 \\
14192100 \\
14192200\end{array}$ & $\begin{array}{r}240 \\
.57 \\
7280 \\
2.72 \\
4.83\end{array}$ & $\begin{array}{r}17.8 \\
124.0 \\
11.2 \\
256.0 \\
227.0\end{array}$ & $\begin{array}{r}44.9 \\
1.1 \\
189.0 \\
3.2 \\
4.0\end{array}$ & $\begin{array}{r}910 \\
365 \\
2150 \\
630 \\
595\end{array}$ & $\begin{array}{r}0.00 \\
0.00 \\
.02 \\
0.00 \\
.10\end{array}$ & $\begin{array}{l}78.0 \\
14.0 \\
70.0 \\
37.0 \\
34.0\end{array}$ & $\begin{array}{r}2.1 \\
.6 \\
3.2 \\
.6 \\
.6\end{array}$ & $\begin{array}{r}90 \\
55 \\
340 \\
105 \\
100\end{array}$ & $\begin{array}{l}44.78 \\
44.70 \\
44.94 \\
44.95 \\
44.97\end{array}$ & $\begin{array}{l}123.23 \\
123.22 \\
123.04 \\
123.08 \\
123.07\end{array}$ & $\begin{array}{l}72 \\
41 \\
64 \\
43 \\
44\end{array}$ & $\begin{array}{l}4.4 \\
4.6 \\
3.7 \\
2.6 \\
2.5\end{array}$ & $\begin{array}{l}31.0 \\
33.0 \\
31.0 \\
32.0 \\
32.0\end{array}$ \\
\hline $\begin{array}{l}14192500 \\
14192800 \\
14193000 \\
14193300 \\
14194000\end{array}$ & $\begin{array}{r}133 \\
1.81 \\
64.7 \\
27.4 \\
502\end{array}$ & $\begin{array}{r}40.5 \\
284.0 \\
124.0 \\
120.0 \\
9.4\end{array}$ & $\begin{array}{r}21.1 \\
2.4 \\
15.1 \\
9.7 \\
49.9\end{array}$ & $\begin{array}{r}950 \\
625 \\
1060 \\
1720 \\
750\end{array}$ & $\begin{array}{l}.08 \\
0.00 \\
0.00 \\
0.00 \\
.10\end{array}$ & $\begin{array}{l}84.0 \\
54.0 \\
85.0 \\
99.9 \\
47.0\end{array}$ & $\begin{array}{l}3.2 \\
.9 \\
3.6 \\
5.6 \\
2.1\end{array}$ & $\begin{array}{r}315 \\
40 \\
20 \\
0 \\
95\end{array}$ & $\begin{array}{l}45.05 \\
45.04 \\
45.14 \\
44.97 \\
45.17\end{array}$ & $\begin{array}{l}123.50 \\
123.47 \\
123.49 \\
123.45 \\
123.21\end{array}$ & $\begin{array}{r}101 \\
70 \\
88 \\
115 \\
78\end{array}$ & $\begin{array}{l}5.0 \\
2.5 \\
4.9 \\
4.9 \\
3.9\end{array}$ & $\begin{array}{l}30.0 \\
29.0 \\
29.0 \\
28.5 \\
30.0\end{array}$ \\
\hline
\end{tabular}


Table 2.--Basin characteristics used in multiple regressions--continued

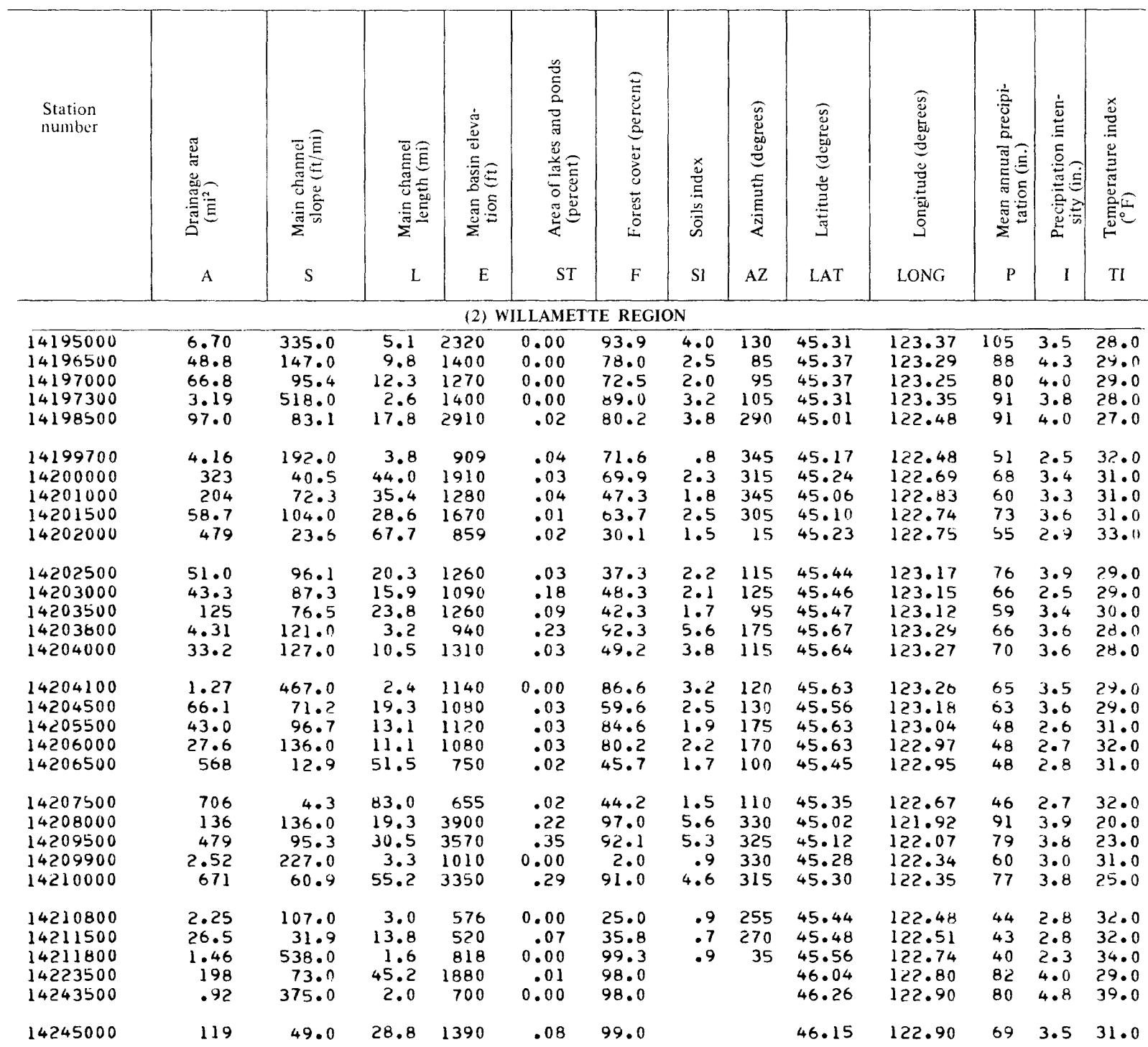


Table 2. - Basin characteristics used in multiple regressions-continued

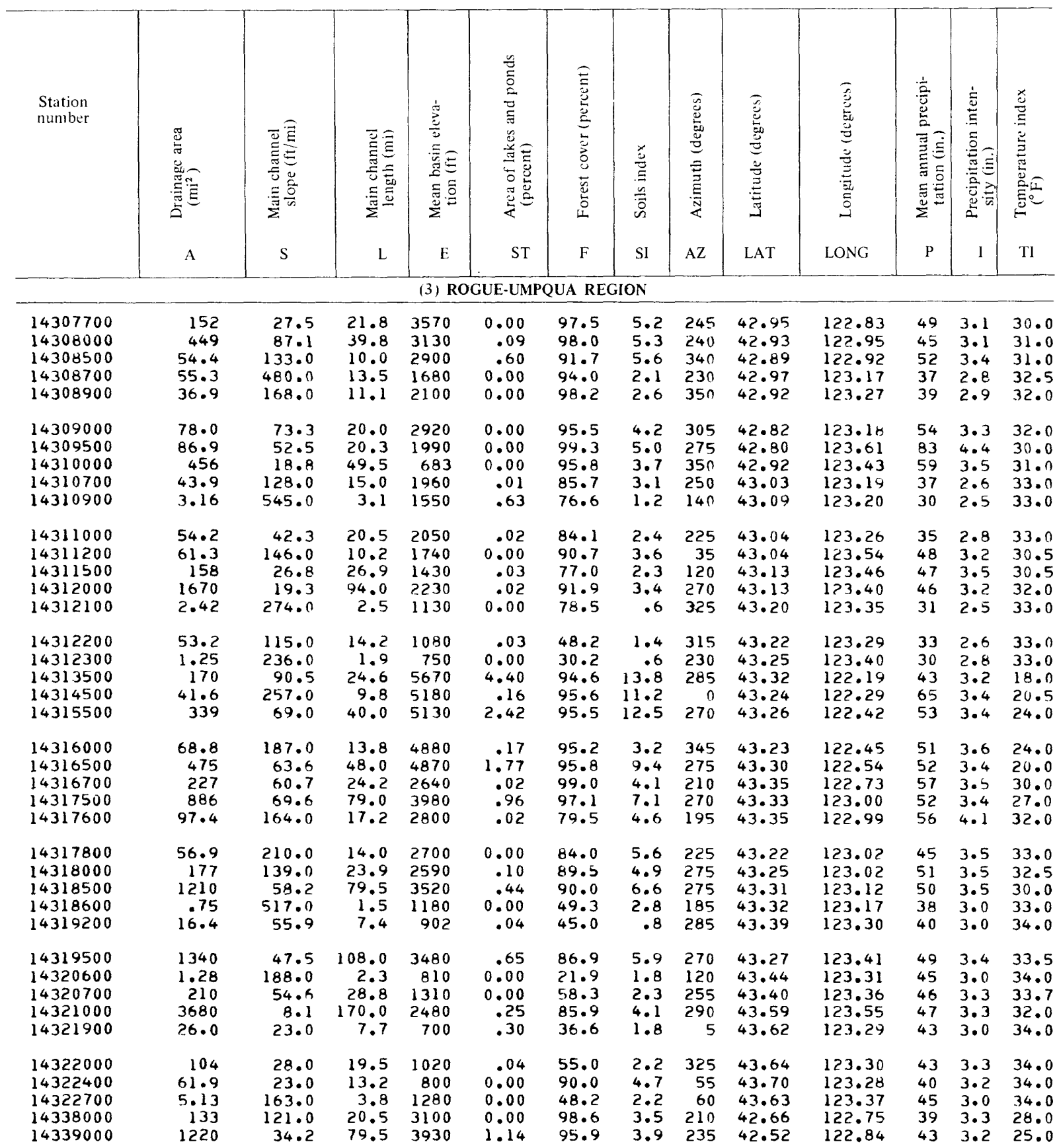


Table 2.-Basin characteristics used in multiple regressions - continued

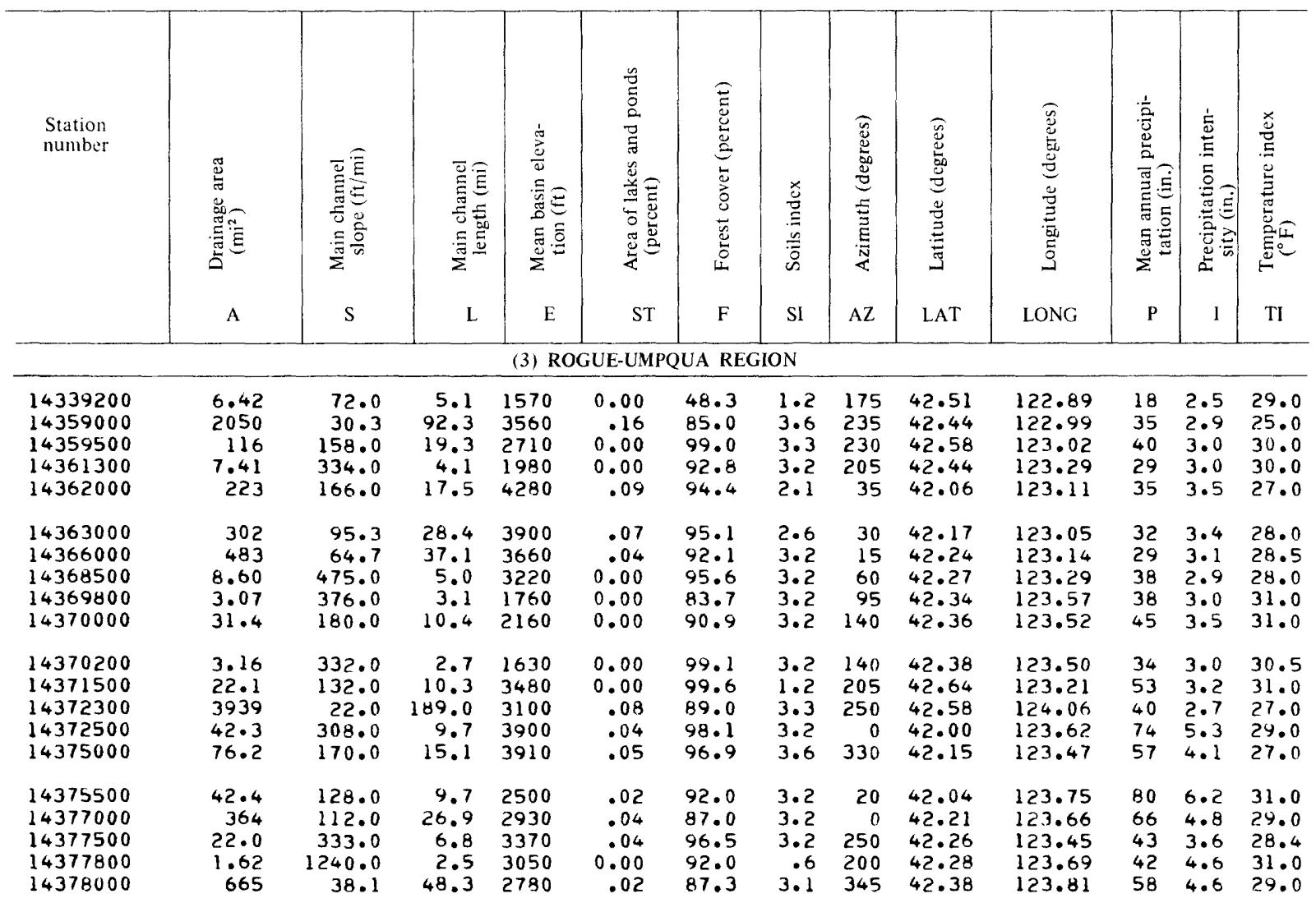


Table 2.-Basin characteristics used in multiple regressions-continued

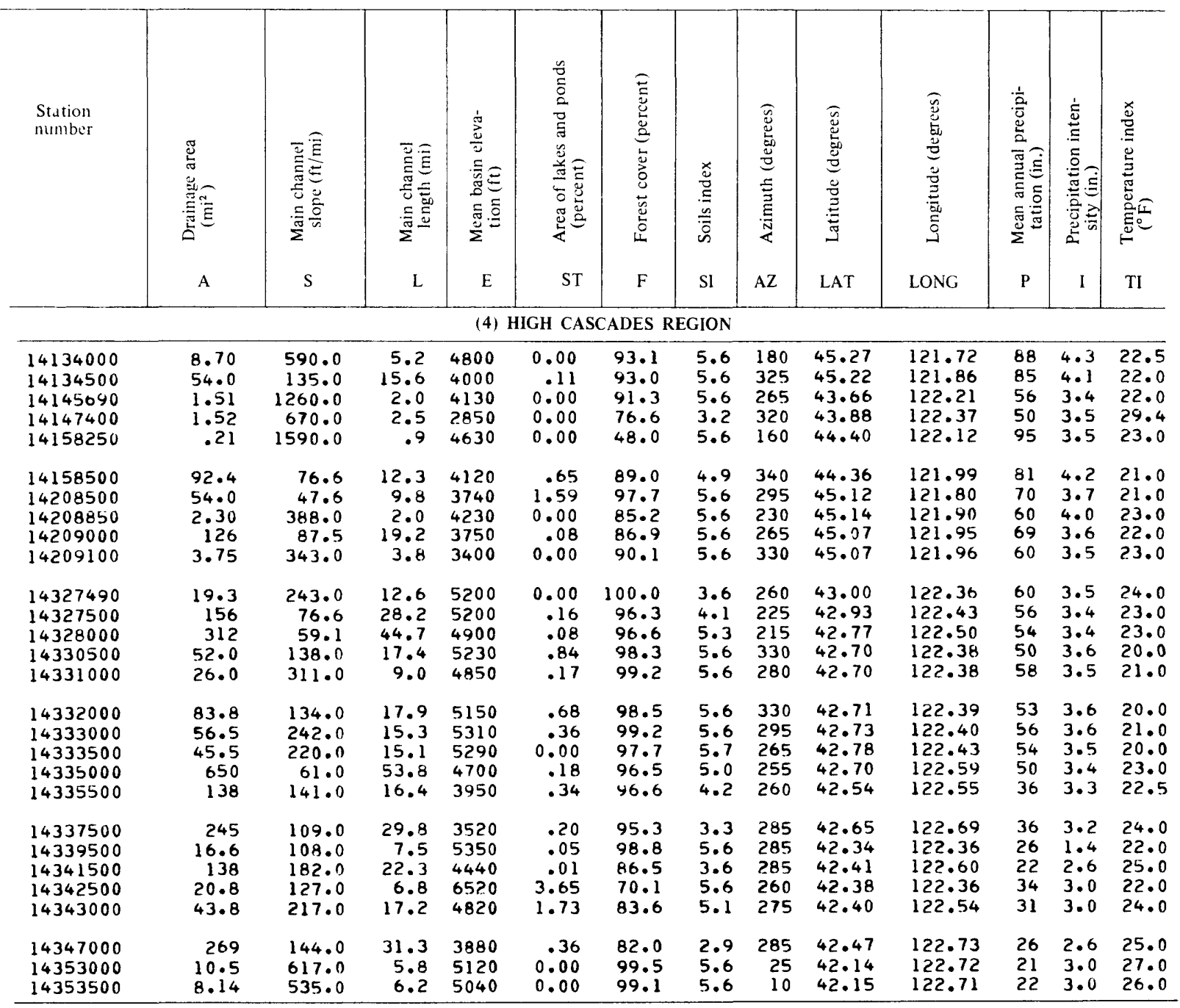


Table 3.-Maximum discharges at gaging stations used in western Oregon flood-frequency analysis

\begin{tabular}{|c|c|c|c|c|}
\hline $\begin{array}{l}\text { Station } \\
\text { number }\end{array}$ & Station name & $\begin{array}{c}\text { Years } \\
\text { of } \\
\text { record }\end{array}$ & Date & $\begin{array}{c}\text { Discharge } \\
\left(\mathrm{ft}^{3} / \mathrm{s}\right)\end{array}$ \\
\hline $\begin{array}{l}11530850 \\
11531000 \\
11533000 \\
14134000 \\
14134500\end{array}$ & $\begin{array}{l}\text { MIDDLE FK SMITH RIVER TRIB. NR OBRIEN, OR } \\
\text { MIODLE FK SMITH RIVER AT GASQUET, CA } \\
\text { LOPEZ CREEK NEAR SMITH RIVER, CA } \\
\text { SALMON RIVER NEAR GOVERNMENT CAMP, OREG. } \\
\text { SALMON RIVER BELOW LINNEY CREEK, OREG. }\end{array}$ & $\begin{array}{l}12 \\
16 \\
12 \\
51 \\
23\end{array}$ & $\begin{array}{l}12-22-64 \\
12-22-64 \\
03-02-72 \\
12-23-64 \\
03-31-31\end{array}$ & $\begin{array}{r}102 \\
41100 \\
570 \\
1300 \\
3670\end{array}$ \\
\hline $\begin{array}{l}14135000 \\
14137000 \\
14138800 \\
14138850 \\
14141500\end{array}$ & $\begin{array}{l}\text { SALMON RIVER AT WELCHES, OREG. } \\
\text { SANDY RIVER NEAR MARMOT, OREG. } \\
\text { BLAZED ALDER CREEK NEAR RHODODENDRON, OREG. } \\
\text { BULL RUN R NR MULTNOMAH FALLS, OREG. } \\
\text { LITTLE SANDY RIVER NEAK BULL RUN, OREG. }\end{array}$ & $\begin{array}{l}13 \\
65 \\
13 \\
10 \\
58\end{array}$ & $\begin{array}{l}03-31-31 \\
12-22-64 \\
12-22-64 \\
01-20-72 \\
12-20-74\end{array}$ & $\begin{array}{r}13000 \\
61400 \\
2610 \\
8610 \\
4280\end{array}$ \\
\hline $\begin{array}{l}14143500 \\
14144000 \\
14144600 \\
14144800 \\
14144870\end{array}$ & $\begin{array}{l}\text { WASHOUGAL RIVER NR WASHOUGAL, WA } \\
\text { LITTLE WASHOUGAL R NR WASHOUGAL, WA } \\
\text { GROENVELD CREEK NEAR CAMAS, WA } \\
\text { MIDDLE FORK WILLAMETTE RIVER NR OAKRIDGE OREG } \\
\text { MIDDLE FK WILLAMETTE R TRIB NR OAKRIDGE, OREG. }\end{array}$ & $\begin{array}{l}28 \\
17 \\
15 \\
18 \\
16\end{array}$ & $\begin{array}{l}01-20-72 \\
12-22-64 \\
12-22-64 \\
12-22-64 \\
12-22-64\end{array}$ & $\begin{array}{r}22600 \\
24300 \\
103 \\
39800 \\
82\end{array}$ \\
\hline $\begin{array}{l}14144900 \\
14145500 \\
14145690 \\
14146000 \\
14146500\end{array}$ & $\begin{array}{l}\text { HILLS CR AB HILLS CR RES, NR OAKRIDGE, OREG. } \\
\text { M F WILLAMETTE R AB SALT CR, NR OAKRIDGE, OREG } \\
\text { SWAMP CREEK NEAR MCCREDIE SPRINGS, OREG. } \\
\text { SALT CREEK NEAK OAKRIDGE, OREG. } \\
\text { SALMON CREEK NEAR OAKRIDGE, OREG. }\end{array}$ & $\begin{array}{l}18 \\
26 \\
10 \\
19 \\
50\end{array}$ & $\begin{array}{l}12-22-64 \\
12-28-45 \\
12-22-64 \\
10-29-50 \\
12-22-64\end{array}$ & $\begin{array}{r}10700 \\
34000 \\
120 \\
4500 \\
11600\end{array}$ \\
\hline $\begin{array}{l}14147400 \\
14147500 \\
14148000 \\
14148700 \\
14150300\end{array}$ & $\begin{array}{l}\text { TUMBLE CREEK NEAR WESTF IR, OREG. } \\
N \text { FK OF M FK WILLAMETTE K NR OAKRIDGE, OREG. } \\
\text { MF WILLAMETTE R NR OAKRIDGE OREG } \\
\text { FERN CREEK NEAR LOWELL, OREG. } \\
\text { FALL CR. NEAK LOWELL, OREG. }\end{array}$ & $\begin{array}{l}11 \\
46 \\
39 \\
21 \\
13\end{array}$ & $\begin{array}{l}12-22-64 \\
12-22-64 \\
12-28-45 \\
02-10-61 \\
01-21-72\end{array}$ & $\begin{array}{r}98 \\
24400 \\
81800 \\
52 \\
12100\end{array}$ \\
\hline $\begin{array}{l}14151000 \\
14151500 \\
14152000 \\
14152500 \\
14153900\end{array}$ & $\begin{array}{l}\text { FALL CREEK BL WINBERRY CR NR FALL CR, OREG. } \\
\text { LITTLE FALL CREEK NEAR FALL CREEK OREG. } \\
\text { MF WILLAMETTE R AT JASPER OREG } \\
\text { COAST FORK WILLAMETTE RIVER AT LONDON, OREG. } \\
\text { PRATHER CREEK NEAR DISSTON, OREO. }\end{array}$ & $\begin{array}{l}30 \\
13 \\
10 \\
41 \\
12\end{array}$ & $\begin{array}{l}12-11-56 \\
12-28-45 \\
11-23-09 \\
12-22-64 \\
02-10-61\end{array}$ & $\begin{array}{r}24700 \\
6110 \\
94000 \\
12500 \\
326\end{array}$ \\
\hline $\begin{array}{l}14154500 \\
14155500 \\
14156000 \\
14156500 \\
14157000\end{array}$ & $\begin{array}{l}\text { ROW RIVER ABOVE PITCHER CREEK, NEAR DORENA, OREG. } \\
\text { ROW RIVER NEAR COTTAGE GROVE, OREG. } \\
\text { MOSBY CREEK NEAR COTTAGE GROVE, OREG. } \\
\text { MOSBY CR AT MOUTH, NR COTTAGE GROVE, OREG. } \\
\text { COAST FK WILLAMETTE R AT SAGINAW OREG. }\end{array}$ & $\begin{array}{l}41 \\
11 \\
11 \\
30 \\
19\end{array}$ & $\begin{array}{l}12-22-64 \\
12-28-45 \\
12-28-45 \\
12-22-64 \\
02-20-27\end{array}$ & $\begin{array}{r}33100 \\
21400 \\
8520 \\
14100 \\
32500\end{array}$ \\
\hline $\begin{array}{l}14158000 \\
14158250 \\
14158500 \\
14159000 \\
14159200\end{array}$ & $\begin{array}{l}\text { WILLAMETTE RIVER AT SPRINGFIELD, OREG. } \\
\text { HACKELMAN CREEK NR UPPER SODA, OREG. } \\
\text { MCKENZIE RIVER AT OUTLET OF CLEAR LAKE, OREG. } \\
\text { MCKENZIE R AT MCKENZIE BRIDGE, OREG. } \\
\text { S FK MCKENZIE R AB COUGAR LK NR RAINBOW, OREG. }\end{array}$ & $\begin{array}{l}36 \\
16 \\
32 \\
49 \\
19\end{array}$ & $\begin{array}{l}12-29-45 \\
12-11-56 \\
12-23-64 \\
01-06-23 \\
12-22-64\end{array}$ & $\begin{array}{r}140000 \\
102 \\
3300 \\
16500 \\
18400\end{array}$ \\
\hline $\begin{array}{l}14159500 \\
14161200 \\
14161500 \\
14161600 \\
14162000\end{array}$ & $\begin{array}{l}\text { SOUTH FORK MCKENZIE RIVER NR RAINBOW, OREG. } \\
\text { LOOKOUT CR TRI NO } 3 \text { NR BLUE RIVER OREG. } \\
\text { LOOKOUT C NR BLUE R GREG } \\
\text { LOOKOUT CR TRIB NR BLUE R, OREG. } \\
\text { BLUE RIVER NR BLUE RIVER, OREG. }\end{array}$ & $\begin{array}{l}16 \\
11 \\
19 \\
15 \\
30\end{array}$ & $\begin{array}{l}12-28-45 \\
12-20-57 \\
12-22-64 \\
12-11-56 \\
12-22-64\end{array}$ & $\begin{array}{r}24500 \\
52 \\
6660 \\
75 \\
19600\end{array}$ \\
\hline
\end{tabular}


Table 3.-Maximum discharges at gaging stations used in western Oregon flood-frequency analysis-continued

\begin{tabular}{|c|c|c|c|c|}
\hline $\begin{array}{l}\text { Station } \\
\text { number }\end{array}$ & Station name & $\begin{array}{l}\text { Years } \\
\text { of } \\
\text { record }\end{array}$ & Date & $\begin{array}{c}\text { Discharge } \\
\left(\mathrm{ft}^{3} / \mathrm{s}\right)\end{array}$ \\
\hline $\begin{array}{l}14162500 \\
14163000 \\
14165000 \\
14165500 \\
14166500\end{array}$ & $\begin{array}{l}\text { MCKENZIE R NR VIDA OREG } \\
\text { GATE CREEK AT VIOA.OREG. } \\
\text { MOHAWK RIVER NR SPRINGFIELO, OREG. } \\
\text { MCKENZIE RIVER NEAR COBURG, OREG. } \\
\text { LONG TOM RIVER NEAR NOTI, OREG. }\end{array}$ & $\begin{array}{l}38 \\
24 \\
31 \\
18 \\
41\end{array}$ & $\begin{array}{l}12-28-45 \\
12-22-64 \\
12-22-64 \\
12-29-45 \\
12-22-55\end{array}$ & $\begin{array}{r}64400 \\
7140 \\
13000 \\
88200 \\
6990\end{array}$ \\
\hline $\begin{array}{l}14167000 \\
14169700 \\
14170500 \\
14171000 \\
14171500\end{array}$ & $\begin{array}{l}\text { COYOTE CREEK NEAR CROW, OREG. } \\
\text { BEAR CREEK NEAR CHESHIRE.OREG. } \\
\text { ROCK CREEK NEAR PHILOMATH, OREG. } \\
\text { MARYS RIVER NEAR PHILOMATH, OREG. } \\
\text { MUDOY CREEK NEAR CORVALLIS, OREG. }\end{array}$ & $\begin{array}{l}36 \\
20 \\
18 \\
36 \\
10\end{array}$ & $\begin{array}{l}02-10-61 \\
01-15-74 \\
12-24-64 \\
1 ?-22-64 \\
12-22-64\end{array}$ & $\begin{array}{r}10500 \\
530 \\
2500 \\
13600 \\
6040\end{array}$ \\
\hline $\begin{array}{l}14172000 \\
14172300 \\
14173500 \\
14174000 \\
14174100\end{array}$ & $\begin{array}{l}\text { CALAPOOIA R AT HOLLEY OREG } \\
\text { BUTTE CR NR PLAINVIEW, OREG. } \\
\text { CALAPOOIA RIVER AT ALBANY, OREG. } \\
\text { WILLAMETTE RIVER AT ALEANY, OREG. } \\
\text { COX CREEK AT ALBANY,OREG. }\end{array}$ & $\begin{array}{l}41 \\
14 \\
36 \\
56 \\
16\end{array}$ & $\begin{array}{l}12-22-64 \\
11-24-60 \\
12-22-55 \\
12-04-61 \\
12-21-64\end{array}$ & $\begin{array}{r}12600 \\
647 \\
32700 \\
340000 \\
1070\end{array}$ \\
\hline $\begin{array}{l}14178000 \\
14178800 \\
14179000 \\
14181500 \\
14181700\end{array}$ & $\begin{array}{l}\text { NORTH SANTIAM R BEL BOULDER CR NR DETROIT, OREG. } \\
\text { WIND CR NR DETROIT,OREG. } \\
\text { BREITENBUSH R ABV CANYON CR NR DETROIT, OREG. } \\
\text { NORTH SANTIAM RIVER AT NIAGARA,OREG. } \\
\text { N SANTIAM RIVER TRIB NR GATES,OREG. }\end{array}$ & $\begin{array}{l}51 \\
23 \\
44 \\
26 \\
17\end{array}$ & $\begin{array}{l}12-22-64 \\
12-21-64 \\
12-22-64 \\
11-22-09 \\
01-30-65\end{array}$ & $\begin{array}{r}26700 \\
231 \\
16900 \\
63200 \\
132\end{array}$ \\
\hline $\begin{array}{l}14182500 \\
14183000 \\
14184900 \\
14185000 \\
14185800\end{array}$ & $\begin{array}{l}\text { LITTLE NORTH SANTIAM RIVER NEAR MEHAMA, OREG. } \\
\text { NORTH SANTIAM RIVER AT MEHAMA, OREG. } \\
\text { SHEEK CREEK NEAR CASCAOIA.OREG. } \\
\text { SOUTH SANTIAM RIVER BELOW CASCADIA, OREG. } \\
\text { MIODLE SANTIAM R NEAR CASCAOIA,OREG. }\end{array}$ & $\begin{array}{l}44 \\
37 \\
24 \\
41 \\
13\end{array}$ & $\begin{array}{l}12-22-64 \\
12-28-45 \\
12-22-64 \\
12-22-64 \\
12-22-64\end{array}$ & $\begin{array}{r}36000 \\
76600 \\
116 \\
27600 \\
22900\end{array}$ \\
\hline $\begin{array}{l}14185900 \\
14186000 \\
14187000 \\
14187500 \\
14188800\end{array}$ & $\begin{array}{l}\text { QUARTZVILLE CREEK NEAR CASCADIA, OREG. } \\
\text { MIDOLE SANTIAM RIVER NEAR FOSTER, OREG. } \\
\text { WILEY CREEK NEAR FOSTER, OREG. } \\
\text { SOUTH SANTIAM RIVER AT WATERLOO, OREG. } \\
\text { THDMAS CREEK NEAR SCIO,OREG. }\end{array}$ & $\begin{array}{l}13 \\
16 \\
26 \\
45 \\
14\end{array}$ & $\begin{array}{l}12-22-64 \\
12-28-45 \\
01-21-72 \\
12-22-64 \\
12-22-64\end{array}$ & $\begin{array}{r}36500 \\
41800 \\
9640 \\
95200 \\
27400\end{array}$ \\
\hline $\begin{array}{l}14189000 \\
14189500 \\
14190000 \\
14190200 \\
14190500\end{array}$ & $\begin{array}{l}\text { SANTIAM R AT JEFFERSON OREG } \\
\text { LUCKIAMUTE RIVER NEAR HOSKINS, OREG. } \\
\text { LUCKIAMUTE R AT PEDEE OREG } \\
\text { WAYMIRE CR NR FALLS CI IY,OREG. } \\
\text { LUCKIAMUTE RIVER NEAR SUVER, OREG. }\end{array}$ & $\begin{array}{l}23 \\
42 \\
30 \\
15 \\
42\end{array}$ & $\begin{array}{l}11-21-21 \\
12-14-46 \\
12-22-64 \\
12-22-64 \\
12-22-64\end{array}$ & $\begin{array}{r}202000 \\
5560 \\
15700 \\
598 \\
32900\end{array}$ \\
\hline $\begin{array}{l}14190600 \\
14191000 \\
14192100 \\
14192200 \\
14192500\end{array}$ & $\begin{array}{l}\text { SOAP CREEK TRIBUTARY NEAR SUVER, OREG. } \\
\text { WILLAMETTE RIVER AT SALEM,OREG. } \\
\text { GLENN CREEK NEAR SALEM,OREG. } \\
\text { GIBSON CREEK NEAR SALEM, OREG. } \\
\text { SOUTH YAMHILL RIVER NEAR WILLAMINA, OREG. }\end{array}$ & $\begin{array}{l}24 \\
51 \\
25 \\
15 \\
42\end{array}$ & $\begin{array}{l}03-02-72 \\
12-04-61 \\
12-21-55 \\
12-23-64 \\
12-22-64\end{array}$ & $\begin{array}{r}86 \\
500000 \\
172 \\
434 \\
19600\end{array}$ \\
\hline $\begin{array}{l}14192800 \\
14193000 \\
14193300 \\
14194000 \\
14195000\end{array}$ & $\begin{array}{l}\text { SOUTH YAMHILL R TRIB NR WILLAMINA,OREG. } \\
\text { WILLAMINIA CREEK NEAR WILLAMINA,OREG. } \\
\text { MILL CREEK NEAR WILLAMINA, OREG. } \\
\text { SOUTH YAMHILL RIVER NEAR WHITESON, OREG. } \\
\text { HASKINS CREEK NEAR MCMINNVILLE, OREG. }\end{array}$ & $\begin{array}{l}23 \\
43 \\
15 \\
36 \\
21\end{array}$ & $\begin{array}{l}12-21-55 \\
12-22-54 \\
12-22-64 \\
12-23-64 \\
03-31-31\end{array}$ & $\begin{array}{r}420 \\
10800 \\
6170 \\
47200 \\
610\end{array}$ \\
\hline
\end{tabular}


Table 3.-Maximum discharges at gaging stations used in western Oregon flood-frequency analysis--continued

\begin{tabular}{|c|c|c|c|c|}
\hline $\begin{array}{l}\text { Station } \\
\text { number }\end{array}$ & Station name & $\begin{array}{l}\text { Years } \\
\text { of } \\
\text { record }\end{array}$ & Date & $\begin{array}{c}\text { Discharge } \\
\left(\mathrm{ft}^{3} / \mathrm{s}\right)\end{array}$ \\
\hline $\begin{array}{l}14196500 \\
14197000 \\
14197300 \\
14198500 \\
14199700\end{array}$ & $\begin{array}{l}\text { NORTH YAMHILL RIVER NR PIKE, OREG. } \\
\text { NORTH YAMHILL R AT PIKE, OREG. } \\
\text { PANTHER CHEEK NEAR CARLTON,OREG. } \\
\text { MOLALLA R AB PC NR WILHOIT, OREG. } \\
\text { BULL CR NR COLTON, OREG. }\end{array}$ & $\begin{array}{l}11 \\
25 \\
16 \\
41 \\
13\end{array}$ & $\begin{array}{l}02-10-49 \\
12-21-55 \\
12-21-64 \\
12-22-64 \\
11-24-60\end{array}$ & $\begin{array}{r}4780 \\
9530 \\
612 \\
24300 \\
293\end{array}$ \\
\hline $\begin{array}{l}14200000 \\
14201000 \\
14201500 \\
14202000 \\
14202500\end{array}$ & $\begin{array}{l}\text { MOLALLA R NR CANBY, OREG. } \\
\text { PUDOING RIVER NEAR MOUNT ANGEL, OREG. } \\
\text { BUTTE CREEK AT MONITOR, OREG. } \\
\text { PUDDING RIVER AT AURORA, OREG. } \\
\text { TUALATIN RIVFR NR GASTON, OREG. }\end{array}$ & $\begin{array}{l}44 \\
26 \\
22 \\
38 \\
20\end{array}$ & $\begin{array}{l}12-22-64 \\
12-22-64 \\
01-21-72 \\
01-07-23 \\
12-21-55\end{array}$ & $\begin{array}{r}43600 \\
16700 \\
7310 \\
27900 \\
8170\end{array}$ \\
\hline $\begin{array}{l}14203000 \\
14203500 \\
14203800 \\
14204000 \\
14204100\end{array}$ & $\begin{array}{l}\text { SCOGGIN CREEK NEAR GASTON, UREG. } \\
\text { TUALATIN RIVFR NEAR DILLEY, OREG. } \\
\text { BEAVER CREEK NEAR GLENWOOD, OREG. } \\
\text { GALES CREEK NR GALES CKEEK, OREG. } \\
\text { BATEMAN CHEE.K NEAR GLENWDOD, OREG. }\end{array}$ & $\begin{array}{l}34 \\
37 \\
17 \\
17 \\
25\end{array}$ & $\begin{array}{l}12-21-55 \\
12-22-64 \\
02-02-63 \\
12-22-64 \\
12-21-55\end{array}$ & $\begin{array}{r}5320 \\
17100 \\
472 \\
3970 \\
145\end{array}$ \\
\hline $\begin{array}{l}14204500 \\
14205500 \\
14206000 \\
14206500 \\
14207500\end{array}$ & $\begin{array}{l}\text { GALES CREEK NEAR FOREST GROVE, OREG. } \\
\text { EAST FORK DAIRY CREEK AT MOUNTAINDALE, OREG. } \\
\text { MCKAY CREEK NEAR NORTH PLAINS, OREG. } \\
\text { TUALATIN RIVER AT FARMINGTON, OREG. } \\
\text { TUALATIN RIVER AT WEST LINN, OREG. }\end{array}$ & $\begin{array}{l}22 \\
11 \\
11 \\
19 \\
46\end{array}$ & $\begin{array}{l}02-17-49 \\
02-17-49 \\
02-17-49 \\
12-22-55 \\
12-23-33\end{array}$ & $\begin{array}{r}6410 \\
1420 \\
2100 \\
24200 \\
29300\end{array}$ \\
\hline $\begin{array}{l}14208000 \\
14208500 \\
14208850 \\
14209000 \\
14209100\end{array}$ & $\begin{array}{l}\text { CLACKAMAS KIVER AT BIG BOTTOM, OREG. } \\
\text { OAK GROVE FORK AT TIMOTHY MEADOWS, OREG. } \\
\text { EAST FORK SHELLROCK CR NR GOVT CAMP, OREG. } \\
\text { OAK GROVE FORK ABOVE POWERPLANT INTAKE, OREG. } \\
\text { KINK CR NR GOVERNMENT CAMP, OREG. }\end{array}$ & $\begin{array}{l}50 \\
16 \\
10 \\
43 \\
19\end{array}$ & $\begin{array}{l}12-22-64 \\
01-07-23 \\
12-24-64 \\
01-07-23 \\
12-21-64\end{array}$ & $\begin{array}{r}11200 \\
770 \\
118 \\
5000 \\
94\end{array}$ \\
\hline $\begin{array}{l}14209500 \\
14209900 \\
14210000 \\
14210800 \\
14211500\end{array}$ & $\begin{array}{l}\text { CLACKAMAS KIVER ABOVE THKEE LYNX CREEK, OREG. } \\
\text { DUROIS CREEK AT ESTACADA,OREG. } \\
\text { CLACKAMAS RIVER AT ESTACADA, OREG. } \\
\text { ROCK CR NR BORING OREG. } \\
\text { JOHNSON CREEK AT SYCAMORE, OREG. }\end{array}$ & $\begin{array}{l}38 \\
20 \\
47 \\
10 \\
36\end{array}$ & $\begin{array}{l}03-31-31 \\
12-22-64 \\
03-31-31 \\
11-20-62 \\
\vdots 2-22-64\end{array}$ & $\begin{array}{r}34800 \\
508 \\
60800 \\
280 \\
2620\end{array}$ \\
\hline $\begin{array}{l}14211800 \\
14223500 \\
14243500 \\
14245000 \\
14248700\end{array}$ & $\begin{array}{l}\text { SALTZMAN CREEK AT PORTLAND, OREG, } \\
\text { KALAMA R BL ITALIAN CR NR KALAMA, WA } \\
\text { DELAMETER CREEK NEAR CASTLE ROCK, WA } \\
\text { COWEMAN RIVER NEAR KELSO, WA } \\
\text { BEAR CREEK NEAR SVENSEN, OREG. }\end{array}$ & $\begin{array}{l}25 \\
26 \\
19 \\
22 \\
10\end{array}$ & $\begin{array}{l}12-21-55 \\
01-20-72 \\
01-19-62 \\
11-20-62 \\
01-11-72\end{array}$ & $\begin{array}{r}306 \\
17900 \\
2420 \\
9720 \\
342\end{array}$ \\
\hline $\begin{array}{l}14251500 \\
14299000 \\
14299500 \\
14300200 \\
14301000\end{array}$ & $\begin{array}{l}\text { YOUNGS RIVER NEAR ASTORIA, OREG. } \\
\text { SO FK NECANICUM RIVER NEAR SEASIDE, OREG. } \\
\text { ASBURY CLEEK NEAR CANNON BEACH, OREG. } \\
\text { OAK RANCH CR NR VERNONIA OREG. } \\
\text { NEHALEM RIVER NEAR FOSS, OREG. }\end{array}$ & $\begin{array}{l}31 \\
16 \\
25 \\
10 \\
37\end{array}$ & $\begin{array}{l}02-10-49 \\
01-25-64 \\
02-10-61 \\
12-21-64 \\
01-20-72\end{array}$ & $\begin{array}{r}4750 \\
3040 \\
314 \\
514 \\
46900\end{array}$ \\
\hline $\begin{array}{l}14301400 \\
14301500 \\
14302500 \\
14303000 \\
14303600\end{array}$ & $\begin{array}{l}\text { PATTERSON CREEK AT BAY CITY, OREG. } \\
\text { WILSON RIVER NEAR TILLAMOOK, OREG. } \\
\text { TRASK RIVER NEAR TILLAMOOK, OREG. } \\
\text { NESTUCCA RIVER NEAR MCMINNVILLE, OREG. } \\
\text { NESTUCCA R NR BEAVER OREG }\end{array}$ & $\begin{array}{l}17 \\
46 \\
37 \\
16 \\
11\end{array}$ & $\begin{array}{l}01-28-65 \\
01-20-72 \\
11-20-21 \\
12-22-33 \\
01-11-72\end{array}$ & $\begin{array}{r}300 \\
36000 \\
30000 \\
1480 \\
29400\end{array}$ \\
\hline
\end{tabular}


Table 3.-Maximum discharges at gaging stations used in western Oregon flood-frequency analysis-continued

\begin{tabular}{|c|c|c|c|c|}
\hline $\begin{array}{l}\text { Station } \\
\text { number }\end{array}$ & Station name & $\begin{array}{l}\text { Years } \\
\text { of } \\
\text { record }\end{array}$ & Date & $\begin{array}{l}\text { Discharge } \\
\left(\mathrm{ft}^{3} / \mathrm{s}\right)\end{array}$ \\
\hline $\begin{array}{l}14303700 \\
14305500 \\
14306100 \\
14306400 \\
14306500\end{array}$ & $\begin{array}{l}\text { ALDER BROOK NR ROSE LODGE,OREG. } \\
\text { SILETZ RIVER AT SILETZ, OREG. } \\
\text { N FK ALSEA R AT ALSEA, OREG. } \\
\text { FIVE RIVFRS NIR FISHER, OREG. } \\
\text { ALSEA RIVER NEAR TIDEWATER, OREG. }\end{array}$ & $\begin{array}{l}23 \\
60 \\
18 \\
14 \\
37\end{array}$ & $\begin{array}{l}01-21-72 \\
11-20-21 \\
12-22-64 \\
01-21-72 \\
12-22-64\end{array}$ & $\begin{array}{r}218 \\
40800 \\
14100 \\
17200 \\
41800\end{array}$ \\
\hline $\begin{array}{l}14306700 \\
14306800 \\
14306810 \\
14306830 \\
14307500\end{array}$ & $\begin{array}{l}\text { NEEDLE BRANCH NEAR SALADO,OREG. } \\
\text { FLYNN CREEK NEAR SALADO OREG. } \\
\text { OEFR CREEK NEAR SALADO,OREG. } \\
\text { LYNDON CREEK NEAR WALDPORT, OREG. } \\
\text { LAKE CREEK AT TRIANGLE, OR }\end{array}$ & $\begin{array}{l}15 \\
15 \\
15 \\
11 \\
32\end{array}$ & $\begin{array}{l}01-11-72 \\
01-21-72 \\
01-28-65 \\
01-28-65 \\
01-15-74\end{array}$ & $\begin{array}{r}64 \\
139 \\
201 \\
162 \\
4640\end{array}$ \\
\hline $\begin{array}{l}14307550 \\
14307610 \\
14307700 \\
14308000 \\
14308500\end{array}$ & $\begin{array}{l}\text { DEADWOOO CREEK TRIB AT ALPHA, OR } \\
\text { SIUSLAW R TRIB NR RAINROCK, OREG. } \\
\text { JACKSON CREEK NEAR TILLER, OREG. } \\
\text { SOUTH UMPQUA RIVER AT TILLER, OREG. } \\
\text { ELK CREEK NEAR OREW, OREG. }\end{array}$ & $\begin{array}{l}12 \\
20 \\
21 \\
38 \\
22\end{array}$ & $\begin{array}{l}12-22-64 \\
01-21-72 \\
12-22-64 \\
12-22-64 \\
12-22-64\end{array}$ & $\begin{array}{r}89 \\
62 \\
21100 \\
60200 \\
8880\end{array}$ \\
\hline $\begin{array}{l}14308700 \\
14308900 \\
14309000 \\
14309500 \\
14310000\end{array}$ & $\begin{array}{l}\text { DAYS CREEK AT DAYS CHEEK, OREG. } \\
\text { CANYON CREEK AT CANYONVILLE, OREG. } \\
\text { COW CREEK NEAR AZALEA, OREG. } \\
\text { WEST FORK COW CREEK NEAR GLENDALE, OREG. } \\
\text { COW CREEK NEAR RIDOLE, OREG. }\end{array}$ & $\begin{array}{l}17 \\
15 \\
48 \\
21 \\
22\end{array}$ & $\begin{array}{l}02-21-56 \\
12-21-55 \\
01-15-74 \\
12-22-64 \\
10-29-50\end{array}$ & $\begin{array}{r}3450 \\
3810 \\
10500 \\
15700 \\
41100\end{array}$ \\
\hline $\begin{array}{l}14310700 \\
14310900 \\
14311000 \\
14311200 \\
14311500\end{array}$ & $\begin{array}{l}\text { SOUTH MYRTLE CREEK NEAR MYRTLE CREEK, OREG. } \\
\text { NF FROZEN CR NR MYRTLE CREEK, OREG. } \\
\text { NORTH MYRTLE CREEK NEAR MYRTLE CREEK, OREG. } \\
\text { OLALLA CREEK NEAR TENMILE, OREG. } \\
\text { LOOKINGGLASS CREEK AT BROCKWAY, OREG. }\end{array}$ & $\begin{array}{l}17 \\
14 \\
21 \\
17 \\
21\end{array}$ & $\begin{array}{l}12-11-56 \\
12-26-55 \\
01-20-64 \\
01-03-66 \\
12-26-55\end{array}$ & $\begin{array}{r}3050 \\
300 \\
3260 \\
9160 \\
35000\end{array}$ \\
\hline $\begin{array}{l}14312000 \\
14312100 \\
14312200 \\
14312300 \\
14313500\end{array}$ & $\begin{array}{l}\text { SOUTH UMPQUA RIVER NEAR BROCKWAY, OREG. } \\
\text { PARROTT CREEK AT ROSEBURG,OREG. } \\
\text { DEER CREEK NEAR ROSEBURG, OREG. } \\
\text { MARKS CREEK NEAR ROSEBURG,OREG. } \\
\text { NORTH UMPQUA R BL LEMOLO LK NR T FALLS,OREG. }\end{array}$ & $\begin{array}{l}46 \\
25 \\
17 \\
17 \\
27\end{array}$ & $\begin{array}{l}12-23-64 \\
12-21-55 \\
12-28-65 \\
0 ?-10-61 \\
06-09-33\end{array}$ & $\begin{array}{r}125000 \\
290 \\
7910 \\
260 \\
1190\end{array}$ \\
\hline $\begin{array}{l}14314500 \\
14315500 \\
14316000 \\
14316500 \\
14316700\end{array}$ & $\begin{array}{l}\text { CLEARWATER RIVER AB IRAP CR NR TOKETTE FLS, OR } \\
\text { NORTH UMPQUA RIVER AT TOKETEE FALLS OREG. } \\
\text { FISH CR AT BIG C R STATION NR T FLS,OREG. } \\
\text { NO UMPQUA R AB COPELAND CR NR T FLS,OREG. } \\
\text { STEAMBOAT CREEK NEAR GLIOE, OREG. }\end{array}$ & $\begin{array}{l}49 \\
24 \\
28 \\
27 \\
21\end{array}$ & $\begin{array}{l}12-23-64 \\
12-31-42 \\
12-22-64 \\
12-22-64 \\
12-22-64\end{array}$ & $\begin{array}{r}1020 \\
5080 \\
12100 \\
40700 \\
S 1000\end{array}$ \\
\hline $\begin{array}{l}14317500 \\
14317600 \\
14317800 \\
14318000 \\
14318500\end{array}$ & $\begin{array}{l}\text { N UMPQUA RIVER AB ROCK CR NR GLIDE OREG } \\
\text { ROCK CREEK NEAR GLIDE, OREG. } \\
\text { CAVITT CREEK NEAR PEEL,OREG. } \\
\text { LITTLE RIVER AT PEEL, OREG. } \\
\text { NORTH UMPQUA RIVER NEAR GLIDE, OREG. }\end{array}$ & $\begin{array}{l}23 \\
17 \\
12 \\
22 \\
20\end{array}$ & $\begin{array}{l}12-22-55 \\
12-22-64 \\
12-11-56 \\
12-11-56 \\
11-22-09\end{array}$ & $\begin{array}{l}68000 \\
22800 \\
10600 \\
21100 \\
94000\end{array}$ \\
\hline $\begin{array}{l}14318600 \\
14319200 \\
14319500 \\
14320600 \\
14320700\end{array}$ & $\begin{array}{l}\text { NORTH UMPQUA R TRIB NR GLIDE OREG. } \\
\text { SUTHERLIN CR AT SUTHERLIN OREG. } \\
\text { NORTH UMPQUA R. AT WINCHESTER, OREG. } \\
\text { CABIN CR TRIB NR OAKLAND, OREG. } \\
\text { CALAPOOYA CREEK NEAR OAKLAND, OREG. }\end{array}$ & $\begin{array}{l}12 \\
12 \\
11 \\
19 \\
18\end{array}$ & $\begin{array}{l}12-26-55 \\
02-10-61 \\
12-22-64 \\
11-23-61 \\
11-23-61\end{array}$ & $\begin{array}{r}188 \\
2250 \\
150000 \\
246 \\
26600\end{array}$ \\
\hline
\end{tabular}


Table 3.-Maximum discharges at gaging stations used in western Oregon flood-frequency analysis-continued

\begin{tabular}{|c|c|c|c|c|}
\hline $\begin{array}{l}\text { Station } \\
\text { number }\end{array}$ & Station name & $\begin{array}{l}\text { Years } \\
\text { of } \\
\text { record }\end{array}$ & Date & $\begin{array}{l}\text { Discharge } \\
\left(\mathrm{ft}^{3} / \mathrm{s}\right)\end{array}$ \\
\hline $\begin{array}{l}14321000 \\
14321900 \\
14322000 \\
14322400 \\
14322700\end{array}$ & $\begin{array}{l}\text { UMPQUA RIVER NEAR ELKTON, OREG. } \\
\text { YONCALLA CR NR YONCALLA OREG. } \\
\text { ELK CREEK NEAR ORAIN. OREG. } \\
\text { PASS CREE NEAR ORAIN, OREG. } \\
\text { BEAR CREEK NEAR ORAIN, OREG. }\end{array}$ & $\begin{array}{l}70 \\
12 \\
22 \\
12 \\
14\end{array}$ & $\begin{array}{l}12-23-64 \\
02-10-61 \\
02-10-61 \\
02-10-61 \\
02-10-61\end{array}$ & $\begin{array}{r}265000 \\
1570 \\
19000 \\
10300 \\
674\end{array}$ \\
\hline $\begin{array}{l}14323200 \\
14323300 \\
1432.4500 \\
14324600 \\
14324700\end{array}$ & $\begin{array}{l}\text { TENMILE CREEK NEAR LAKESIOE, OREG. } \\
\text { EEL CREEK AT LAKESIOE,OREG. } \\
\text { WEST FORK MILLICOMA RIVER NEAR ALLEGANY, OREG. } \\
\text { S FK COQUILLE. R AB PANTHER CR, NR ILLAHE, OREG. } \\
\text { SOUTH FORK COQUILLE RIVER NEAR ILLAHE, OREG. }\end{array}$ & $\begin{array}{l}19 \\
19 \\
22 \\
14 \\
18\end{array}$ & $\begin{array}{l}12-26-64 \\
01-17-74 \\
11-24-60 \\
12-22-64 \\
12-22-64\end{array}$ & $\begin{array}{r}3330 \\
316 \\
8100 \\
8840 \\
12000\end{array}$ \\
\hline $\begin{array}{l}14324900 \\
14325000 \\
14326500 \\
14326600 \\
14326800\end{array}$ & $\begin{array}{l}\text { SF COQUILLE R NR POWERS ORES } \\
\text { SOUTH FORK COQUILLE RIVEK AT POWERS, OREG. } \\
\text { MIDOLE FK CORUILLE R NR MYRTLE POINT OREG. } \\
\text { GETTYS CREEK NEAR MYRTLE POINT, OREG. } \\
\text { NORTH FORK COQUILLE RIVEK NR FAIRVIEW, OREG. }\end{array}$ & $\begin{array}{l}14 \\
58 \\
17 \\
24 \\
13\end{array}$ & $\begin{array}{l}12-22-64 \\
12-22-64 \\
10-31-24 \\
02-10-61 \\
03-02-72\end{array}$ & $\begin{array}{r}29600 \\
48900 \\
31800 \\
245 \\
7760\end{array}$ \\
\hline $\begin{array}{l}14327000 \\
14327100 \\
14327240 \\
14327400 \\
14327490\end{array}$ & $\begin{array}{l}\text { NFK COQUILLE R NR MYRTLE POINT, OREG. } \\
\text { GEIGER CREEK NEAR BANOON,OKEG. } \\
\text { MILBURY CREEK NEAR PORT ORFORO, OREG. } \\
\text { DRY RUN CR NR PORT ORFORO,OREG. } \\
\text { NATIONAL CREEK NEAR UNION CREEK, OREG. }\end{array}$ & $\begin{array}{l}24 \\
16 \\
11 \\
22 \\
11\end{array}$ & $\begin{array}{l}12-23-64 \\
02-10-61 \\
01-04-66 \\
01-18-71 \\
12-22-64\end{array}$ & $\begin{array}{r}38400 \\
206 \\
286 \\
213 \\
475\end{array}$ \\
\hline $\begin{array}{l}14327500 \\
14328000 \\
14330500 \\
14331000 \\
14332000\end{array}$ & $\begin{array}{l}\text { ROGUF RIVER ABOVE BYBEE CREEK, NR UNION CR, OREG } \\
\text { ROGUE RIVER ABOVE PROSPECT, OREG. } \\
\text { S FK ROGUE R AB IMNAHA CR NR PROSPECT OREG. } \\
\text { IMNAHA CREEK NEAR PROSPECT, OREG. } \\
\text { SOUTH FORK ROGUE RIVER NEAR PROSPECT, OREG. }\end{array}$ & $\begin{array}{l}22 \\
55 \\
18 \\
18 \\
34\end{array}$ & $\begin{array}{l}11-29-42 \\
12-22-64 \\
12-01-42 \\
02-13-45 \\
12-22-64\end{array}$ & $\begin{array}{r}4430 \\
22400 \\
2170 \\
500 \\
7010\end{array}$ \\
\hline $\begin{array}{l}14333000 \\
14333500 \\
14335000 \\
14335500 \\
14337500\end{array}$ & $\begin{array}{l}\text { MIDDLE FK ROGUE RIVER NR PROSPECT OREG. } \\
\text { RED BLANKET CREEK NEAR PROSPECT, OREG. } \\
\text { ROGUE R BL S FK ROGUE R NR PROSPECT OREG. } \\
\text { SOUTH FORK BIG BUTTE CR NR BUTTE FALLS,OREG. } \\
\text { GIG BUTTE CREEK NFAR MCLEOD,OREG. }\end{array}$ & $\begin{array}{l}30 \\
50 \\
34 \\
56 \\
20\end{array}$ & $\begin{array}{l}12-22-55 \\
02-13-45 \\
12-22-64 \\
12-22-64 \\
12-22-55\end{array}$ & $\begin{array}{r}3230 \\
9900 \\
55000 \\
12600 \\
8950\end{array}$ \\
\hline $\begin{array}{l}14338000 \\
14339000 \\
14339200 \\
14339500 \\
14341500\end{array}$ & $\begin{array}{l}\text { ELK CREEK NEAR TRAIL, OREG. } \\
\text { ROGUE R AT OODGE RR NR EAGLE POINT, OKEG. } \\
\text { CONSTANCF. CR NR SAMS VALLEY OREG. } \\
\text { S FK LITTLE BUTTE CR AT BIG ELK RG STA, OR } \\
\text { SOUTH FORK LITTLE BUTTE CR VR LAKECREEK, OREG. }\end{array}$ & $\begin{array}{l}31 \\
38 \\
10 \\
22 \\
55\end{array}$ & $\begin{array}{l}12-22-64 \\
12-22-64 \\
12-02-62 \\
05-25-42 \\
12-02-62\end{array}$ & $\begin{array}{r}19200 \\
87600 \\
950 \\
145 \\
7660\end{array}$ \\
\hline $\begin{array}{l}14342500 \\
14343000 \\
14347000 \\
14353000 \\
14353500\end{array}$ & $\begin{array}{l}\text { NO FK LITTLE BUTTE CR AT F L NR LAKECREEK, OREG. } \\
\text { NO FK LITTLE BUTTE CR NR LAKECREEK,OKEG. } \\
\text { LITTLE BUTTE CREEK AR EAGLE POINT OREG. } \\
\text { W FK ASHLAND CREEK NEAR ASHLAND, OREG. } \\
\text { EAST FK ASHLAND CREEK NEAR ASHLAND, OREG. }\end{array}$ & $\begin{array}{l}59 \\
51 \\
10 \\
19 \\
19\end{array}$ & $\begin{array}{l}07-17-59 \\
12-22-64 \\
10-30-24 \\
01-15-74 \\
01-15-74\end{array}$ & $\begin{array}{l}163 \\
1750 \\
7000 \\
4780 \\
5630\end{array}$ \\
\hline $\begin{array}{l}14359000 \\
14359500 \\
14361300 \\
14362000 \\
14363000\end{array}$ & $\begin{array}{l}\text { ROGUE RIVER AT RAYGOLD, NEAR CENTRAL POINT, OREG } \\
\text { EVANS CR NR BYBEE SPRINGS NR ROGUE R OREG. } \\
\text { JONES CREEK NEAR GRANTS PASS,OREG. } \\
\text { APPLEGATE RIVER NEAR COPPER, OREG. } \\
\text { APPLEGATE RIVER NEAR RUCH, OREG. }\end{array}$ & $\begin{array}{l}71 \\
13 \\
25 \\
38 \\
31\end{array}$ & $\begin{array}{l}12-23-64 \\
02-20-27 \\
02-22-56 \\
01-15-74 \\
02-20-27\end{array}$ & $\begin{array}{r}131000 \\
11100 \\
1350 \\
29800 \\
20000\end{array}$ \\
\hline
\end{tabular}


Table 3.-Maximum discharges at gaging stations used in western Oregon flood-frequency analysis-continued

\begin{tabular}{|c|c|c|c|c|}
\hline $\begin{array}{l}\text { Station } \\
\text { number }\end{array}$ & Station name & $\begin{array}{l}\text { Years } \\
\text { of } \\
\text { record }\end{array}$ & Date & $\begin{array}{l}\text { Discharge } \\
\left(\mathrm{ft}^{3} / \mathrm{s}\right)\end{array}$ \\
\hline $\begin{array}{l}14366000 \\
14368500 \\
14369800 \\
14370000 \\
14370200\end{array}$ & $\begin{array}{l}\text { APPLEGATE RIVER NEAR APPLEGATE, OREG. } \\
\text { POWELL CREEK NEAR WILLIAMS, OREG. } \\
\text { GUTCHFRKNIFE CREEK NEAR WONDER.OREG. } \\
\text { SLATE CREEK AT WONDER, OREG. } \\
\text { ROUND PRAIRIE CREEK NR WILDERVILLE.OREG. }\end{array}$ & $\begin{array}{l}38 \\
12 \\
16 \\
19 \\
16\end{array}$ & $\begin{array}{l}01-15-74 \\
01-18-53 \\
01-03-66 \\
1>22-64 \\
01-03-66\end{array}$ & $\begin{array}{r}37200 \\
1110 \\
432 \\
4650 \\
375\end{array}$ \\
\hline $\begin{array}{l}14371500 \\
14372300 \\
14372500 \\
14375000 \\
14375500\end{array}$ & $\begin{array}{l}\text { GRAVE CREEK AT PEASE BFIDGE, NEAR PLACER, OREG. } \\
\text { ROGUE RIVER NEAR AGNESS, OREG. } \\
\text { E F ILLINOIS RIVER NEAR TAKILMA,OREG. } \\
\text { SUCKER CREEK NEAR HOLLAND, OREG. } \\
\text { W FK ILLINOIS R PL ROCK CR VR OSRIEN, OR }\end{array}$ & $\begin{array}{l}34 \\
16 \\
39 \\
24 \\
22\end{array}$ & $\begin{array}{l}12-22-64 \\
12-23-64 \\
12-22-64 \\
12-22-64 \\
12-24-64\end{array}$ & $\begin{array}{r}6240 \\
290000 \\
15700 \\
17500 \\
16100\end{array}$ \\
\hline $\begin{array}{l}14377000 \\
14377500 \\
14377800 \\
14378000\end{array}$ & $\begin{array}{l}\text { ILLINOIS RIVER AT KERBY, OREG. } \\
\text { DEER CPEEK NEAR ORYDEN, OREG. } \\
\text { SNAILBACK CR NR SELMA,OREG. } \\
\text { ILLINOIS R NR SELMA, OREG. }\end{array}$ & $\begin{array}{l}35 \\
15 \\
17 \\
12\end{array}$ & $\begin{array}{l}12-22-55 \\
01-18-53 \\
12-21-64 \\
12-22-64\end{array}$ & $\begin{array}{r}56800 \\
5000 \\
329 \\
160000\end{array}$ \\
\hline
\end{tabular}


Table 4.-Discharges for selected flood-frequencies at gaging stations

\begin{tabular}{|c|c|c|c|c|c|c|}
\hline \multirow[b]{2}{*}{$\begin{array}{l}\text { Station } \\
\text { number }\end{array}$} & \multicolumn{6}{|c|}{$\begin{array}{l}\text { Peak discharge, in cubic feet per second, for selected exceedance probabilities } \\
\text { (indicated recurrence interval) }\end{array}$} \\
\hline & $\begin{array}{l}0.50 \\
(2-y r)\end{array}$ & $\begin{array}{c}0.20 \\
(5-y r)\end{array}$ & $\begin{array}{c}0.10 \\
(10-y r)\end{array}$ & $\begin{array}{c}0.04 \\
(25-y r)\end{array}$ & $\begin{array}{c}0.02 \\
(50-y r)\end{array}$ & $\begin{array}{c}0.01 \\
(100-y r)\end{array}$ \\
\hline \multicolumn{7}{|c|}{ (1) COAST REGION } \\
\hline $\begin{array}{l}11530850 \\
11531000 \\
11533000 \\
14248700 \\
14251500\end{array}$ & $\begin{array}{r}40 \\
14600 \\
152 \\
147 \\
2960\end{array}$ & $\begin{array}{r}60 \\
21100 \\
286 \\
207 \\
3590\end{array}$ & $\begin{array}{r}74 \\
25500 \\
393 \\
249 \\
3990\end{array}$ & $\begin{array}{r}91 \\
30800 \\
546 \\
304 \\
4450\end{array}$ & $\begin{array}{r}104 \\
34800 \\
671 \\
348 \\
4780\end{array}$ & $\begin{array}{r}117 \\
38700 \\
805 \\
393 \\
5110\end{array}$ \\
\hline $\begin{array}{l}14299000 \\
14299500 \\
14300200 \\
14301000 \\
14301400\end{array}$ & $\begin{array}{r}1900 \\
212 \\
285 \\
27900 \\
109\end{array}$ & $\begin{array}{r}2360 \\
253 \\
415 \\
35200 \\
164\end{array}$ & $\begin{array}{r}2650 \\
277 \\
509 \\
39800 \\
205\end{array}$ & $\begin{array}{r}3000 \\
306 \\
636 \\
45500 \\
259\end{array}$ & $\begin{array}{r}3260 \\
327 \\
736 \\
49600 \\
303\end{array}$ & $\begin{array}{r}3510 \\
347 \\
841 \\
53600 \\
349\end{array}$ \\
\hline $\begin{array}{l}14301500 \\
14302500 \\
14303000 \\
14303600 \\
14303700\end{array}$ & $\begin{array}{r}17400 \\
12900 \\
727 \\
14500 \\
88\end{array}$ & $\begin{array}{r}22600 \\
16900 \\
1130 \\
20100 \\
132\end{array}$ & $\begin{array}{r}26000 \\
19500 \\
1440 \\
24000 \\
153\end{array}$ & $\begin{array}{r}30100 \\
22900 \\
1880 \\
28900 \\
204\end{array}$ & $\begin{array}{r}33200 \\
25400 \\
2240 \\
32600 \\
236\end{array}$ & $\begin{array}{r}36300 \\
27900 \\
2620 \\
36300 \\
269\end{array}$ \\
\hline $\begin{array}{l}14305500 \\
14306100 \\
14306400 \\
14306500 \\
14306700\end{array}$ & $\begin{array}{r}20900 \\
5120 \\
8680 \\
20600 \\
30\end{array}$ & $\begin{array}{r}26600 \\
7350 \\
12000 \\
27300 \\
39\end{array}$ & $\begin{array}{r}30200 \\
8990 \\
14200 \\
31700 \\
45\end{array}$ & $\begin{array}{r}34300 \\
10900 \\
17100 \\
37100 \\
51\end{array}$ & $\begin{array}{r}37300 \\
12400 \\
19200 \\
41000 \\
56\end{array}$ & $\begin{array}{r}40200 \\
14000 \\
21300 \\
45000 \\
61\end{array}$ \\
\hline $\begin{array}{l}14306800 \\
14306810 \\
14306830 \\
14307500 \\
14307550\end{array}$ & $\begin{array}{r}63 \\
103 \\
55 \\
2<30 \\
53\end{array}$ & $\begin{array}{r}86 \\
135 \\
88 \\
3400 \\
71\end{array}$ & $\begin{array}{r}101 \\
156 \\
112 \\
4240 \\
92\end{array}$ & $\begin{array}{r}120 \\
182 \\
144 \\
5360 \\
96\end{array}$ & $\begin{array}{r}135 \\
201 \\
170 \\
6230 \\
106\end{array}$ & $\begin{array}{r}149 \\
219 \\
147 \\
7140 \\
116\end{array}$ \\
\hline $\begin{array}{l}14307610 \\
14323200 \\
14323300 \\
14324500 \\
14324600\end{array}$ & $\begin{array}{r}25 \\
2190 \\
164 \\
5380 \\
3780\end{array}$ & $\begin{array}{r}37 \\
2910 \\
219 \\
7150 \\
4900\end{array}$ & $\begin{array}{r}46 \\
3340 \\
253 \\
8240 \\
5560\end{array}$ & $\begin{array}{r}57 \\
3860 \\
293 \\
9550 \\
6330\end{array}$ & $\begin{array}{r}66 \\
4220 \\
321 \\
10500 \\
6850\end{array}$ & $\begin{array}{r}75 \\
4560 \\
348 \\
11400 \\
7340\end{array}$ \\
\hline $\begin{array}{l}14324700 \\
14324900 \\
14325000 \\
14326500 \\
14326600\end{array}$ & $\begin{array}{r}4850 \\
13100 \\
15300 \\
14800 \\
137\end{array}$ & $\begin{array}{r}6650 \\
16800 \\
21900 \\
21100 \\
190\end{array}$ & $\begin{array}{r}7760 \\
19000 \\
26200 \\
25000 \\
223\end{array}$ & $\begin{array}{r}9080 \\
21500 \\
31600 \\
29700 \\
262\end{array}$ & $\begin{array}{r}10000 \\
23200 \\
35500 \\
33100 \\
290\end{array}$ & $\begin{array}{r}10900 \\
24800 \\
39400 \\
36300 \\
316\end{array}$ \\
\hline $\begin{array}{l}14326800 \\
14327000 \\
14327100 \\
14327240 \\
14327400\end{array}$ & $\begin{array}{r}4980 \\
13400 \\
95 \\
111 \\
107\end{array}$ & $\begin{array}{r}6810 \\
21000 \\
141 \\
190 \\
158\end{array}$ & $\begin{array}{r}7960 \\
25200 \\
170 \\
256 \\
191\end{array}$ & $\begin{array}{r}9330 \\
32800 \\
206 \\
357 \\
231\end{array}$ & $\begin{array}{r}10300 \\
37800 \\
232 \\
447 \\
261\end{array}$ & $\begin{array}{r}11200 \\
42700 \\
257 \\
548 \\
289\end{array}$ \\
\hline
\end{tabular}


Table 4.-Discharges for selected flood-frequencies at gaging stations-continued

\begin{tabular}{|c|c|c|c|c|c|c|}
\hline \multirow[b]{2}{*}{$\begin{array}{l}\text { Station } \\
\text { number }\end{array}$} & \multicolumn{6}{|c|}{$\begin{array}{l}\text { Peak discharge, in cubic feet per second, for selected exceedance probabilities } \\
\text { (indicated recurrence interval) }\end{array}$} \\
\hline & $\begin{array}{l}0.50 \\
(2-y r)\end{array}$ & $\begin{array}{l}0.20 \\
(S-y r)\end{array}$ & $\begin{array}{l}0.10 \\
(10-y r)\end{array}$ & $\begin{array}{l}0.04 \\
(25-\mathrm{yr})\end{array}$ & $\begin{array}{c}0.02 \\
(50-y r)\end{array}$ & $\begin{array}{c}0.01 \\
(100-y r)\end{array}$ \\
\hline \multicolumn{7}{|c|}{ (2) WILLAMETTE REGION } \\
\hline $\begin{array}{l}14135000 \\
14137000 \\
14138800 \\
14138850 \\
14141500\end{array}$ & $\begin{array}{r}5490 \\
14000 \\
1180 \\
6160 \\
2270\end{array}$ & $\begin{array}{r}7590 \\
21300 \\
1650 \\
7180 \\
3200\end{array}$ & $\begin{array}{r}8990 \\
26600 \\
1980 \\
7780 \\
3850\end{array}$ & $\begin{array}{r}10800 \\
33700 \\
2390 \\
8470 \\
4700\end{array}$ & $\begin{array}{r}12100 \\
39400 \\
2700 \\
8940 \\
5350\end{array}$ & $\begin{array}{r}13400 \\
45300 \\
3020 \\
9400 \\
6030\end{array}$ \\
\hline $\begin{array}{l}14143500 \\
14144000 \\
14144600 \\
14144800 \\
14144870\end{array}$ & $\begin{array}{r}13500 \\
1250 \\
42 \\
8140 \\
25\end{array}$ & $\begin{array}{r}16600 \\
1710 \\
57 \\
13700 \\
44\end{array}$ & $\begin{array}{r}18500 \\
2020 \\
66 \\
18300 \\
59\end{array}$ & $\begin{array}{r}20700 \\
2410 \\
77 \\
24900 \\
81\end{array}$ & $\begin{array}{r}22300 \\
2700 \\
85 \\
30600 \\
100\end{array}$ & $\begin{array}{r}23800 \\
2990 \\
94 \\
36900 \\
122\end{array}$ \\
\hline $\begin{array}{l}14144900 \\
14145500 \\
14146000 \\
14146500 \\
14147500\end{array}$ & $\begin{array}{r}2010 \\
11700 \\
1670 \\
3150 \\
7350\end{array}$ & $\begin{array}{r}3330 \\
20800 \\
2830 \\
5300 \\
11500\end{array}$ & $\begin{array}{r}4380 \\
28400 \\
3760 \\
7020 \\
14800\end{array}$ & $\begin{array}{r}5890 \\
39800 \\
5120 \\
9520 \\
19300\end{array}$ & $\begin{array}{r}7170 \\
49800 \\
6270 \\
11600 \\
23000\end{array}$ & $\begin{array}{r}8570 \\
61000 \\
7550 \\
14000 \\
27000\end{array}$ \\
\hline $\begin{array}{l}14148000 \\
14148700 \\
14150300 \\
14151000 \\
14151500\end{array}$ & $\begin{array}{r}26900 \\
23 \\
6140 \\
9700 \\
2470\end{array}$ & $\begin{array}{r}44900 \\
34 \\
9640 \\
15000 \\
4250\end{array}$ & $\begin{array}{r}59200 \\
43 \\
12300 \\
19000 \\
5710\end{array}$ & $\begin{array}{r}79800 \\
53 \\
16100 \\
24500 \\
7880\end{array}$ & $\begin{array}{r}97100 \\
62 \\
19200 \\
29000 \\
9750\end{array}$ & $\begin{array}{r}116000 \\
71 \\
22600 \\
33700 \\
11800\end{array}$ \\
\hline $\begin{array}{l}14152000 \\
14152500 \\
14153900 \\
14154500 \\
14155500\end{array}$ & $\begin{array}{r}45500 \\
3700 \\
207 \\
11200 \\
11100\end{array}$ & $\begin{array}{r}81400 \\
5960 \\
288 \\
16900 \\
17300\end{array}$ & $\begin{array}{r}111000 \\
7670 \\
344 \\
20900 \\
22000\end{array}$ & $\begin{array}{r}157000 \\
10100 \\
417 \\
26400 \\
28500\end{array}$ & $\begin{array}{r}197000 \\
12000 \\
475 \\
30700 \\
33800\end{array}$ & $\begin{array}{r}242000 \\
14100 \\
534 \\
35100 \\
39500\end{array}$ \\
\hline $\begin{array}{l}14156000 \\
14156500 \\
14157000 \\
14158000 \\
14159000\end{array}$ & $\begin{array}{r}3570 \\
4860 \\
18300 \\
55500 \\
6360\end{array}$ & $\begin{array}{r}5820 \\
7450 \\
24300 \\
78500 \\
9330\end{array}$ & $\begin{array}{r}7570 \\
9350 \\
28400 \\
94500 \\
11400\end{array}$ & $\begin{array}{r}10100 \\
12000 \\
33600 \\
116000 \\
14200\end{array}$ & $\begin{array}{r}12100 \\
14100 \\
37500 \\
132000 \\
16300\end{array}$ & $\begin{array}{r}14400 \\
16300 \\
41500 \\
149000 \\
18500\end{array}$ \\
\hline $\begin{array}{l}14159200 \\
14159500 \\
14161200 \\
14161500 \\
14161600\end{array}$ & $\begin{array}{r}4980 \\
9500 \\
33 \\
1860 \\
35\end{array}$ & $\begin{array}{r}7580 \\
15300 \\
45 \\
2850 \\
55\end{array}$ & $\begin{array}{r}9480 \\
19800 \\
54 \\
3570 \\
70\end{array}$ & $\begin{array}{r}12100 \\
26200 \\
66 \\
4570 \\
90\end{array}$ & $\begin{array}{r}14200 \\
31400 \\
75 \\
5360 \\
107\end{array}$ & $\begin{array}{r}16400 \\
37000 \\
84 \\
6190 \\
124\end{array}$ \\
\hline $\begin{array}{l}14162000 \\
14162500 \\
14163000 \\
14165000 \\
14165500\end{array}$ & $\begin{array}{r}5920 \\
28300 \\
2970 \\
5820 \\
49000\end{array}$ & $\begin{array}{r}8900 \\
40100 \\
46110 \\
8570 \\
68700\end{array}$ & $\begin{array}{r}11100 \\
48300 \\
5830 \\
10500 \\
81800\end{array}$ & $\begin{array}{r}14000 \\
58900 \\
7540 \\
13200 \\
99000\end{array}$ & $\begin{array}{r}16300 \\
67000 \\
8940 \\
15300 \\
112000\end{array}$ & $\begin{array}{r}18800 \\
75300 \\
10400 \\
17500 \\
126000\end{array}$ \\
\hline
\end{tabular}


Table 4.-Discharges for selected flood-frequencies at gaging stations-continued

\begin{tabular}{|c|c|c|c|c|c|c|}
\hline \multirow[b]{2}{*}{$\begin{array}{l}\text { Station } \\
\text { number }\end{array}$} & \multicolumn{6}{|c|}{$\begin{array}{l}\text { Peak discharge, in cubic feet per second, for selected exceedance probabilities } \\
\text { (indicated recurrence interval) }\end{array}$} \\
\hline & $\begin{array}{l}0.50 \\
(2-y r)\end{array}$ & $\begin{array}{c}0.20 \\
(5-y r)\end{array}$ & $\begin{array}{c}0.10 \\
(10-y r)\end{array}$ & $\begin{array}{l}0.04 \\
(25-\mathrm{yr})\end{array}$ & $\begin{array}{c}0.02 \\
(50-\mathrm{yr})\end{array}$ & $\begin{array}{c}0.01 \\
(100-y r)\end{array}$ \\
\hline \multicolumn{7}{|c|}{ (2) WILLAMETTE REGION } \\
\hline $\begin{array}{l}14166500 \\
14167000 \\
14169700 \\
14170500 \\
14171000\end{array}$ & $\begin{array}{r}3150 \\
4130 \\
234 \\
1070 \\
5990\end{array}$ & $\begin{array}{r}4710 \\
7680 \\
353 \\
1510 \\
8630\end{array}$ & $\begin{array}{r}5790 \\
10600 \\
439 \\
1820 \\
10500\end{array}$ & $\begin{array}{r}7210 \\
14900 \\
556 \\
2220 \\
12900\end{array}$ & $\begin{array}{r}8300 \\
18500 \\
649 \\
2520 \\
14700\end{array}$ & $\begin{array}{r}9410 \\
22600 \\
746 \\
2840 \\
16600\end{array}$ \\
\hline $\begin{array}{l}14171500 \\
14172000 \\
14172300 \\
14173500 \\
14174000\end{array}$ & $\begin{array}{r}3220 \\
5620 \\
237 \\
12500 \\
106000\end{array}$ & $\begin{array}{r}4190 \\
8270 \\
391 \\
20100 \\
160000\end{array}$ & $\begin{array}{r}4820 \\
10200 \\
512 \\
26000 \\
199000\end{array}$ & $\begin{array}{r}5610 \\
12800 \\
688 \\
34200 \\
254000\end{array}$ & $\begin{array}{r}6200 \\
14800 \\
837 \\
41000 \\
299000\end{array}$ & $\begin{array}{r}6790 \\
16900 \\
1000 \\
48200 \\
346000\end{array}$ \\
\hline $\begin{array}{l}14174100 \\
14178000 \\
14178800 \\
14179000 \\
14181500\end{array}$ & $\begin{array}{r}533 \\
7510 \\
86 \\
6260 \\
21300\end{array}$ & $\begin{array}{r}750 \\
11600 \\
127 \\
8890 \\
34700\end{array}$ & $\begin{array}{r}903 \\
14600 \\
157 \\
10700 \\
44900\end{array}$ & $\begin{array}{r}1110 \\
18700 \\
196 \\
13100 \\
59300\end{array}$ & $\begin{array}{r}1260 \\
21900 \\
220 \\
14900 \\
71000\end{array}$ & $\begin{array}{r}1430 \\
25400 \\
257 \\
16700 \\
83000\end{array}$ \\
\hline $\begin{array}{l}14181700 \\
14182500 \\
14183000 \\
14184900 \\
14185000\end{array}$ & $\begin{array}{r}01 \\
13500 \\
34100 \\
55 \\
11700\end{array}$ & $\begin{array}{r}86 \\
18900 \\
48600 \\
80 \\
17500\end{array}$ & $\begin{array}{r}103 \\
22700 \\
58500 \\
98 \\
21700\end{array}$ & $\begin{array}{r}124 \\
27600 \\
71200 \\
122 \\
27300\end{array}$ & $\begin{array}{r}141 \\
31400 \\
80800 \\
141 \\
31700\end{array}$ & $\begin{array}{r}158 \\
35300 \\
90600 \\
161 \\
36300\end{array}$ \\
\hline $\begin{array}{l}14185800 \\
14185900 \\
14186000 \\
14187000 \\
14187500\end{array}$ & $\begin{array}{r}8210 \\
12000 \\
20900 \\
3410 \\
37500\end{array}$ & $\begin{array}{r}11800 \\
17900 \\
28400 \\
5300 \\
54200\end{array}$ & $\begin{array}{r}14300 \\
22100 \\
33600 \\
6730 \\
65900\end{array}$ & $\begin{array}{r}17700 \\
27900 \\
40200 \\
8730 \\
81500\end{array}$ & $\begin{array}{l}20200 \\
32400 \\
45300 \\
10400 \\
93700\end{array}$ & $\begin{array}{r}22900 \\
37200 \\
50500 \\
12100 \\
106000\end{array}$ \\
\hline $\begin{array}{l}14188800 \\
14189000 \\
14189500 \\
14190000 \\
14190200\end{array}$ & $\begin{array}{r}8250 \\
77000 \\
3020 \\
6410 \\
248\end{array}$ & $\begin{array}{r}12900 \\
120000 \\
3960 \\
8700 \\
384\end{array}$ & $\begin{array}{r}16500 \\
152000 \\
4580 \\
10300 \\
486\end{array}$ & $\begin{array}{r}21500 \\
199000 \\
5360 \\
12300 \\
628\end{array}$ & $\begin{array}{r}25600 \\
237000 \\
5940 \\
13900 \\
744\end{array}$ & $\begin{array}{r}30000 \\
278000 \\
6530 \\
15500 \\
867\end{array}$ \\
\hline $\begin{array}{l}14190500 \\
14190600 \\
14191000 \\
14192100 \\
14192200\end{array}$ & $\begin{array}{r}11800 \\
44 \\
165000 \\
72 \\
139\end{array}$ & $\begin{array}{r}17100 \\
60 \\
241000 \\
117 \\
212\end{array}$ & $\begin{array}{r}21000 \\
71 \\
298000 \\
152 \\
267\end{array}$ & $\begin{array}{r}26300 \\
86 \\
376000 \\
203 \\
343\end{array}$ & $\begin{array}{r}30500 \\
97 \\
439000 \\
246 \\
405\end{array}$ & $\begin{array}{r}34900 \\
108 \\
507000 \\
293 \\
472\end{array}$ \\
\hline $\begin{array}{l}14192500 \\
14192800 \\
14193000 \\
14193300 \\
14194000\end{array}$ & $\begin{array}{r}9520 \\
129 \\
3850 \\
3060 \\
22300\end{array}$ & $\begin{array}{r}12300 \\
199 \\
5240 \\
4100 \\
28800\end{array}$ & $\begin{array}{r}14100 \\
252 \\
6210 \\
4780 \\
33100\end{array}$ & $\begin{array}{r}16400 \\
324 \\
7500 \\
5660 \\
38500\end{array}$ & $\begin{array}{r}18000 \\
382 \\
8490 \\
6330 \\
42600\end{array}$ & $\begin{array}{r}19700 \\
444 \\
9530 \\
7000 \\
46800\end{array}$ \\
\hline
\end{tabular}


Table 4. - Discharges for selected flood-frequencies at gaging stations-continued

\begin{tabular}{|c|c|c|c|c|c|c|}
\hline \multirow[b]{2}{*}{$\begin{array}{l}\text { Station } \\
\text { number }\end{array}$} & \multicolumn{6}{|c|}{$\begin{array}{l}\text { Peak discharge, in cubic feet per second, for selected exceedance probabilitics } \\
\text { (indicated recurrence intervat) }\end{array}$} \\
\hline & $\begin{array}{l}0.50 \\
(2-y r)\end{array}$ & $\begin{array}{c}0.20 \\
(5-\mathrm{yr})\end{array}$ & $\begin{array}{c}0.10 \\
(10-y r)\end{array}$ & $\begin{array}{c}0.04 \\
(25-\mathrm{yr})\end{array}$ & $\begin{array}{c}0.02 \\
(50-\mathrm{yr})\end{array}$ & $\begin{array}{c}0.01 \\
(100-y r)\end{array}$ \\
\hline \multicolumn{7}{|c|}{ (2) WILLAMETTE REGION } \\
\hline $\begin{array}{l}14195000 \\
14196500 \\
14197000 \\
14197300 \\
14198500\end{array}$ & $\begin{array}{r}287 \\
2770 \\
4060 \\
224 \\
7660\end{array}$ & $\begin{array}{r}397 \\
3550 \\
5630 \\
325 \\
10800\end{array}$ & $\begin{array}{r}473 \\
4060 \\
6730 \\
399 \\
13100\end{array}$ & $\begin{array}{r}574 \\
4710 \\
8190 \\
499 \\
16100\end{array}$ & $\begin{array}{r}651 \\
5190 \\
9330 \\
579 \\
18500\end{array}$ & $\begin{array}{r}732 \\
5670 \\
10500 \\
664 \\
20900\end{array}$ \\
\hline $\begin{array}{l}14149700 \\
14200000 \\
14201000 \\
14201500 \\
14202000\end{array}$ & $\begin{array}{r}116 \\
13800 \\
6080 \\
3080 \\
8650\end{array}$ & $\begin{array}{r}195 \\
20200 \\
9470 \\
4610 \\
13600\end{array}$ & $\begin{array}{r}257 \\
24800 \\
12000 \\
5730 \\
17500\end{array}$ & $\begin{array}{r}346 \\
31100 \\
15500 \\
7260 \\
22800\end{array}$ & $\begin{array}{r}421 \\
36000 \\
18400 \\
8480 \\
27300\end{array}$ & $\begin{array}{r}502 \\
41200 \\
21400 \\
9700 \\
32100\end{array}$ \\
\hline $\begin{array}{l}14202500 \\
14203000 \\
14203500 \\
14203800 \\
14204000\end{array}$ & $\begin{array}{r}2940 \\
1810 \\
5090 \\
200 \\
1890\end{array}$ & $\begin{array}{r}3990 \\
2610 \\
7530 \\
269 \\
2880\end{array}$ & $\begin{array}{r}4700 \\
3190 \\
9360 \\
360 \\
3630\end{array}$ & $\begin{array}{r}5620 \\
3940 \\
11900 \\
468 \\
4670\end{array}$ & $\begin{array}{r}6330 \\
4620 \\
14000 \\
561 \\
5520\end{array}$ & $\begin{array}{r}7050 \\
5300 \\
16300 \\
668 \\
6420\end{array}$ \\
\hline $\begin{array}{l}14204100 \\
14204500 \\
14205500 \\
14206000 \\
14206500\end{array}$ & $\begin{array}{r}01 \\
3170 \\
1150 \\
954 \\
10200\end{array}$ & $\begin{array}{r}87 \\
4640 \\
1290 \\
1250 \\
15000\end{array}$ & $\begin{array}{r}106 \\
5710 \\
1380 \\
1440 \\
18500\end{array}$ & $\begin{array}{r}132 \\
7170 \\
1470 \\
1680 \\
23300\end{array}$ & $\begin{array}{r}152 \\
8330 \\
1540 \\
1870 \\
27100\end{array}$ & $\begin{array}{r}173 \\
9550 \\
1610 \\
2050 \\
31100\end{array}$ \\
\hline $\begin{array}{l}14207500 \\
14208000 \\
14209500 \\
14209900 \\
14210000\end{array}$ & $\begin{array}{r}10100 \\
3010 \\
16900 \\
84 \\
24400\end{array}$ & $\begin{array}{r}14700 \\
4750 \\
25100 \\
103 \\
37600\end{array}$ & $\begin{array}{r}18000 \\
6030 \\
30700 \\
231 \\
46900\end{array}$ & $\begin{array}{r}22400 \\
7780 \\
38100 \\
335 \\
59300\end{array}$ & $\begin{array}{r}25900 \\
9170 \\
43700 \\
426 \\
68900\end{array}$ & $\begin{array}{r}29600 \\
10600 \\
49300 \\
529 \\
78700\end{array}$ \\
\hline $\begin{array}{l}14210800 \\
14211500 \\
14211800 \\
14223500 \\
14243500\end{array}$ & $\begin{array}{r}151 \\
1170 \\
104 \\
10300 \\
1260\end{array}$ & $\begin{array}{r}234 \\
1800 \\
168 \\
12900 \\
1770\end{array}$ & $\begin{array}{r}296 \\
2250 \\
217 \\
14500 \\
2110\end{array}$ & $\begin{array}{r}379 \\
2840 \\
287 \\
16500 \\
2560\end{array}$ & $\begin{array}{r}446 \\
3300 \\
344 \\
17900 \\
2910\end{array}$ & $\begin{array}{r}516 \\
3770 \\
406 \\
19400 \\
3260\end{array}$ \\
\hline 14245000 & 4860 & 6340 & 7300 & 8510 & 9410 & 10300 \\
\hline
\end{tabular}


Table 4.-Discharges for selected flood-frequencies at gaging stations-continued

\begin{tabular}{|c|c|c|c|c|c|c|}
\hline \multirow[b]{2}{*}{$\begin{array}{l}\text { Station } \\
\text { number }\end{array}$} & \multicolumn{6}{|c|}{$\begin{array}{l}\text { Peak discharge, in cubic feet per second, for selected exceedance probabilities } \\
\text { (indicated recurrence interval) }\end{array}$} \\
\hline & $\begin{array}{l}0.50 \\
(2-y r)\end{array}$ & $\begin{array}{c}0.20 \\
(5-y r)\end{array}$ & $\begin{array}{c}0.10 \\
(10-y r)\end{array}$ & $\begin{array}{c}0.04 \\
(25-\mathrm{yr})\end{array}$ & $\begin{array}{c}0.02 \\
(50-y r)\end{array}$ & $\begin{array}{c}0.01 \\
(100-y r)\end{array}$ \\
\hline \multicolumn{7}{|c|}{ (3) ROGUE-UMPQUA REGION } \\
\hline $\begin{array}{l}14307700 \\
14308000 \\
14308500 \\
14308700 \\
14308900\end{array}$ & $\begin{array}{r}5770 \\
17900 \\
2910 \\
1580 \\
2530\end{array}$ & $\begin{array}{r}9680 \\
28600 \\
5070 \\
2370 \\
3140\end{array}$ & $\begin{array}{r}12800 \\
36600 \\
6800 \\
2940 \\
3510\end{array}$ & $\begin{array}{r}17200 \\
47500 \\
9320 \\
3690 \\
3960\end{array}$ & $\begin{array}{r}20900 \\
56300 \\
11400 \\
4280 \\
4280\end{array}$ & $\begin{array}{r}25000 \\
65500 \\
13800 \\
4890 \\
4590\end{array}$ \\
\hline $\begin{array}{l}14309000 \\
14309500 \\
14310000 \\
14310700 \\
14310900\end{array}$ & $\begin{array}{r}2430 \\
7300 \\
21400 \\
1830 \\
147\end{array}$ & $\begin{array}{r}4490 \\
10200 \\
31300 \\
2510 \\
232\end{array}$ & $\begin{array}{r}6090 \\
12100 \\
37700 \\
2960 \\
294\end{array}$ & $\begin{array}{r}8330 \\
14500 \\
45500 \\
3520 \\
380\end{array}$ & $\begin{array}{r}10100 \\
16200 \\
51200 \\
3950 \\
449\end{array}$ & $\begin{array}{r}12000 \\
17900 \\
56700 \\
4370 \\
521\end{array}$ \\
\hline $\begin{array}{l}14311000 \\
14311200 \\
14311500 \\
14312000 \\
14312100\end{array}$ & $\begin{array}{r}2030 \\
3920 \\
11500 \\
49400 \\
163\end{array}$ & $\begin{array}{r}2500 \\
6600 \\
17900 \\
76100 \\
187\end{array}$ & $\begin{array}{r}2780 \\
8620 \\
22600 \\
94400 \\
202\end{array}$ & $\begin{array}{r}3110 \\
11400 \\
28800 \\
118000 \\
218\end{array}$ & $\begin{array}{r}3350 \\
13600 \\
33700 \\
135000 \\
229\end{array}$ & $\begin{array}{r}3540 \\
16000 \\
38800 \\
153000 \\
240\end{array}$ \\
\hline $\begin{array}{l}14312200 \\
14312300 \\
14313500 \\
14314500 \\
14315500\end{array}$ & $\begin{array}{r}4000 \\
132 \\
710 \\
320 \\
2560\end{array}$ & $\begin{array}{r}5390 \\
198 \\
929 \\
421 \\
3560\end{array}$ & $\begin{array}{r}6300 \\
244 \\
1070 \\
492 \\
4250\end{array}$ & $\begin{array}{r}7430 \\
305 \\
1260 \\
586 \\
5180\end{array}$ & $\begin{array}{r}8270 \\
353 \\
1390 \\
660 \\
5890\end{array}$ & $\begin{array}{r}9110 \\
402 \\
1530 \\
736 \\
6640\end{array}$ \\
\hline $\begin{array}{l}14316000 \\
14316500 \\
14316700 \\
14317500 \\
14317600\end{array}$ & $\begin{array}{r}2100 \\
7750 \\
15000 \\
24500 \\
6270\end{array}$ & $\begin{array}{r}3790 \\
13700 \\
22600 \\
37100 \\
10300\end{array}$ & $\begin{array}{r}5220 \\
18700 \\
28100 \\
46300 \\
13400\end{array}$ & $\begin{array}{r}7430 \\
26200 \\
35700 \\
58700 \\
17800\end{array}$ & $\begin{array}{r}9380 \\
32700 \\
41800 \\
68700 \\
21500\end{array}$ & $\begin{array}{l}11600 \\
40100 \\
48300 \\
79100 \\
25500\end{array}$ \\
\hline $\begin{array}{l}14317800 \\
14318000 \\
14318500 \\
14318600 \\
14319200\end{array}$ & $\begin{array}{r}3520 \\
9740 \\
39500 \\
55 \\
1310\end{array}$ & $\begin{array}{r}6090 \\
14500 \\
57400 \\
87 \\
1920\end{array}$ & $\begin{array}{r}8150 \\
17900 \\
69900 \\
111 \\
2330\end{array}$ & $\begin{array}{r}11200 \\
22500 \\
86400 \\
144 \\
2880\end{array}$ & $\begin{array}{r}13700 \\
26000 \\
99100 \\
170 \\
3300\end{array}$ & $\begin{array}{r}16500 \\
29800 \\
112000 \\
198 \\
3730\end{array}$ \\
\hline $\begin{array}{l}14319500 \\
14320600 \\
14320700 \\
14321000 \\
14321900\end{array}$ & $\begin{array}{r}49300 \\
152 \\
11700 \\
94500 \\
1250\end{array}$ & $\begin{array}{r}74700 \\
217 \\
19700 \\
141000 \\
1490\end{array}$ & $\begin{array}{r}92900 \\
262 \\
25800 \\
173000 \\
1640\end{array}$ & $\begin{array}{r}117000 \\
320 \\
34500 \\
216000 \\
1810\end{array}$ & $\begin{array}{r}136000 \\
364 \\
41700 \\
249000 \\
1930\end{array}$ & $\begin{array}{r}156000 \\
409 \\
49400 \\
284000 \\
2050\end{array}$ \\
\hline $\begin{array}{l}14322000 \\
14322400 \\
14322700 \\
14338000 \\
14339000\end{array}$ & $\begin{array}{r}5600 \\
4040 \\
370 \\
5500 \\
21100\end{array}$ & $\begin{array}{r}10600 \\
6720 \\
492 \\
8970 \\
35500\end{array}$ & $\begin{array}{r}14900 \\
8780 \\
572 \\
11600 \\
46800\end{array}$ & $\begin{array}{r}21500 \\
11700 \\
673 \\
15300 \\
63100\end{array}$ & $\begin{array}{r}27300 \\
14100 \\
747 \\
18400 \\
76700\end{array}$ & $\begin{array}{r}33800 \\
16700 \\
822 \\
21700 \\
91600\end{array}$ \\
\hline
\end{tabular}


Table 4.-Discharges for selected flood-frequencies at gaging stations-continued

\begin{tabular}{|c|c|c|c|c|c|c|}
\hline \multirow[b]{2}{*}{$\begin{array}{l}\text { Station } \\
\text { number }\end{array}$} & \multicolumn{6}{|c|}{$\begin{array}{l}\text { Peak discharge, in cubic feet per second, for selected exceedance probabilities } \\
\text { (indicated recurrence interval) }\end{array}$} \\
\hline & $\begin{array}{l}0.50 \\
(2-y r)\end{array}$ & $\begin{array}{c}0.20 \\
(5-y r)\end{array}$ & $\begin{array}{c}0.10 \\
(10-y r)\end{array}$ & $\begin{array}{c}0.04 \\
(25-\mathrm{yr})\end{array}$ & $\begin{array}{c}0.02 \\
(50-y r)\end{array}$ & $\begin{array}{c}0.01 \\
(100-y r)\end{array}$ \\
\hline \multicolumn{7}{|c|}{ (3) ROGUE-UMPQUA REGION } \\
\hline $\begin{array}{l}14339200 \\
14359000 \\
14359500 \\
14361300 \\
14302000\end{array}$ & $\begin{array}{r}425 \\
26200 \\
3880 \\
319 \\
6710\end{array}$ & $\begin{array}{r}631 \\
46500 \\
7340 \\
533 \\
13300\end{array}$ & $\begin{array}{r}775 \\
63300 \\
10200 \\
693 \\
18700\end{array}$ & $\begin{array}{r}965 \\
88700 \\
14500 \\
912 \\
26600\end{array}$ & $\begin{array}{r}1110 \\
111000 \\
18100 \\
1090 \\
33300\end{array}$ & $\begin{array}{r}1200 \\
136000 \\
22100 \\
1270 \\
40600\end{array}$ \\
\hline $\begin{array}{l}14363000 \\
14366000 \\
14368500 \\
14369800 \\
14370000\end{array}$ & $\begin{array}{r}4940 \\
9110 \\
410 \\
228 \\
2600\end{array}$ & $\begin{array}{r}9770 \\
18700 \\
937 \\
348 \\
4070\end{array}$ & $\begin{array}{r}13800 \\
26700 \\
1430 \\
431 \\
5110\end{array}$ & $\begin{array}{r}19900 \\
38900 \\
2230 \\
538 \\
6470\end{array}$ & $\begin{array}{r}25000 \\
49200 \\
2960 \\
620 \\
7520\end{array}$ & $\begin{array}{r}30700 \\
60500 \\
3800 \\
702 \\
8580\end{array}$ \\
\hline $\begin{array}{l}14370200 \\
14371500 \\
14372300 \\
14372500 \\
14375000\end{array}$ & $\begin{array}{r}180 \\
1690 \\
106000 \\
4190 \\
3200\end{array}$ & $\begin{array}{r}319 \\
2840 \\
182000 \\
6340 \\
6150\end{array}$ & $\begin{array}{r}427 \\
3680 \\
236000 \\
7790 \\
8530\end{array}$ & $\begin{array}{r}580 \\
4810 \\
308000 \\
9630 \\
11900\end{array}$ & $\begin{array}{r}704 \\
5690 \\
363000 \\
11000 \\
14800\end{array}$ & $\begin{array}{r}837 \\
6600 \\
418000 \\
12400 \\
17800\end{array}$ \\
\hline $\begin{array}{l}14375500 \\
14377000 \\
14377500 \\
14377800 \\
14378000\end{array}$ & $\begin{array}{r}5840 \\
24800 \\
1950 \\
157 \\
54400\end{array}$ & $\begin{array}{r}8280 \\
38100 \\
3500 \\
227 \\
78600\end{array}$ & $\begin{array}{r}9810 \\
47000 \\
4680 \\
273 \\
94100\end{array}$ & $\begin{array}{r}11700 \\
58200 \\
6330 \\
329 \\
113000\end{array}$ & $\begin{array}{r}13000 \\
66500 \\
7640 \\
370 \\
127000\end{array}$ & $\begin{array}{r}14200 \\
74600 \\
9030 \\
410 \\
140000\end{array}$ \\
\hline
\end{tabular}


Table 4. - Discharges for selected flood-frequencies at gaging stations-continued

\begin{tabular}{|c|c|c|c|c|c|c|}
\hline \multirow[b]{2}{*}{$\begin{array}{l}\text { Station } \\
\text { number }\end{array}$} & \multicolumn{6}{|c|}{$\begin{array}{l}\text { Peak discharge, in cubic feet per second, for selected exceedance probabilities } \\
\text { (indicated recurrence interval) }\end{array}$} \\
\hline & $\begin{array}{l}0.50 \\
(2-y r)\end{array}$ & $\begin{array}{c}0.20 \\
(5-y r)\end{array}$ & $\begin{array}{c}0.10 \\
(10-y r)\end{array}$ & $\begin{array}{c}0.04 \\
(25-\mathrm{yr})\end{array}$ & $\begin{array}{c}0.02 \\
(50-\mathrm{yr})\end{array}$ & $\begin{array}{c}0.01 \\
(100-y r)\end{array}$ \\
\hline \multicolumn{7}{|c|}{ (4) HIGH CASCADES REGION } \\
\hline $\begin{array}{l}14134000 \\
14134500 \\
14145690 \\
14147400 \\
14138250\end{array}$ & $\begin{array}{r}290 \\
1380 \\
12 \\
36 \\
35\end{array}$ & $\begin{array}{r}444 \\
2100 \\
37 \\
80 \\
60\end{array}$ & $\begin{array}{r}559 \\
2620 \\
69 \\
124 \\
79\end{array}$ & $\begin{array}{r}717 \\
3320 \\
135 \\
199 \\
106\end{array}$ & $\begin{array}{r}846 \\
3860 \\
209 \\
271 \\
129\end{array}$ & $\begin{array}{r}982 \\
4420 \\
313 \\
360 \\
153\end{array}$ \\
\hline $\begin{array}{l}14158500 \\
14208500 \\
14208850 \\
14209000 \\
14209100\end{array}$ & $\begin{array}{r}1470 \\
503 \\
64 \\
1680 \\
49\end{array}$ & $\begin{array}{r}2030 \\
712 \\
93 \\
2430 \\
76\end{array}$ & $\begin{array}{r}2410 \\
855 \\
113 \\
2950 \\
95\end{array}$ & $\begin{array}{r}2900 \\
1040 \\
139 \\
3660 \\
120\end{array}$ & $\begin{array}{r}3270 \\
1180 \\
159 \\
4210 \\
140\end{array}$ & $\begin{array}{r}3640 \\
1320 \\
179 \\
4780 \\
161\end{array}$ \\
\hline $\begin{array}{l}14327490 \\
14327500 \\
14328000 \\
14330500 \\
14331000\end{array}$ & $\begin{array}{r}177 \\
2250 \\
4790 \\
735 \\
171\end{array}$ & $\begin{array}{r}253 \\
3070 \\
7620 \\
1110 \\
286\end{array}$ & $\begin{array}{r}307 \\
3640 \\
9880 \\
1380 \\
377\end{array}$ & $\begin{array}{r}381 \\
4390 \\
13200 \\
1760 \\
510\end{array}$ & $\begin{array}{r}438 \\
4970 \\
16000 \\
2060 \\
622\end{array}$ & $\begin{array}{r}498 \\
5560 \\
19200 \\
2380 \\
745\end{array}$ \\
\hline $\begin{array}{l}14332000 \\
14333000 \\
14333500 \\
14335000 \\
14335500\end{array}$ & $\begin{array}{r}1050 \\
909 \\
569 \\
9040 \\
818\end{array}$ & $\begin{array}{r}1870 \\
1510 \\
1130 \\
15300 \\
1590\end{array}$ & $\begin{array}{r}2560 \\
1990 \\
1680 \\
20300 \\
7320\end{array}$ & $\begin{array}{r}3610 \\
2700 \\
2620 \\
27900 \\
3560\end{array}$ & $\begin{array}{r}4530 \\
3300 \\
3550 \\
34400 \\
4750\end{array}$ & $\begin{array}{r}5590 \\
3960 \\
4720 \\
41600 \\
6210\end{array}$ \\
\hline $\begin{array}{l}14337500 \\
14339500 \\
14341500 \\
14342500 \\
14343000\end{array}$ & $\begin{array}{r}3420 \\
104 \\
1130 \\
121 \\
247\end{array}$ & $\begin{array}{r}5540 \\
116 \\
2290 \\
143 \\
421\end{array}$ & $\begin{array}{r}7170 \\
124 \\
3310 \\
154 \\
573\end{array}$ & $\begin{array}{r}9460 \\
132 \\
4910 \\
167 \\
812\end{array}$ & $\begin{array}{r}11300 \\
138 \\
6330 \\
176 \\
1030\end{array}$ & $\begin{array}{r}13400 \\
144 \\
7950 \\
183 \\
1290\end{array}$ \\
\hline $\begin{array}{l}14347000 \\
14353000 \\
14353500\end{array}$ & $\begin{array}{r}3100 \\
92 \\
94\end{array}$ & $\begin{array}{r}4850 \\
267 \\
278\end{array}$ & $\begin{array}{r}6130 \\
467 \\
491\end{array}$ & $\begin{array}{r}7880 \\
847 \\
900\end{array}$ & $\begin{array}{l}9270 \\
1240 \\
1330\end{array}$ & $\begin{array}{r}10700 \\
1760 \\
1890\end{array}$ \\
\hline
\end{tabular}

